\title{
From the Arab Lands to the Malabar Coast The Arabic mawlid as a Literary Genre and a Traveling Text
}

\author{
INES WEINRICH \\ Westfälische Wilhelms-Universität Münster, Germany
}

\begin{abstract}
This article explores the potential of literary-liturgical texts in tracing developments in intra-religious contacts. It deals with mawlid, which is both a literary genre and a devotional practice. By the thirteenth century, mawlid was established in various parts of the Muslim world as an annual feast and a public practice to commemorate the birthday of the prophet Muhammad. One element of such festivities was the liturgical reading of a literary composition centring on the prophet's birth and early life, in most cases simply termed mawlid. The article focusses on the intra-religious transcultural transfer of mawlid writing, namely from the Arab world to Muslim communities on the Malabar Coast, the western coast of South India. In analysing such a transfer, I identify texts and people that travelled between the Mediterranean and the Indian Ocean and examine the literary practices. The findings indicate that there is plausibility for dating the first Arabic mawlid compositions from Malabar to the early sixteenth century. I show how a mawlid text supposedly composed in thirteenth-century Andalusia and circulating as far as Yemen served as a genre model for the presumed first Arabic mawlid composition in Malabar. Furthermore, the social context of the Malabar composition draws on a transformation in the function of mawlid readings, which were, in the late fifteenth century, no longer limited to commemorating the birth anniversary. Finally, the mawlid's aesthetic features and performance practices allowed a new experience of Arabic and reflect the rise of Muslim educational institutions and a growing Muslim population in the coastal towns of Malabar.
\end{abstract}

KEYWORDS mawlid, mawlūd, Muslim ritual, Sharaf al-anām (Sharrafa l-anām), Manqūṣ (Manqoos) Mawlid, Malabar, Arabic Cosmopolis

\section{Introduction}

The phenomenon of Arabic Muslim texts that, due to their immense popularity, travelled between the Arab world and South Asian Muslims is well known. In this article, I am going to focus on mawlid texts, keeping in mind that mawlid is both a literary genre and a religious practice to commemorate the birth of the prophet Muhammad. Mawlid texts became 
widespread from the late twelfth century onwards in different Arab regions and subsequently moved across languages, regions, and cultures (Abū l-Fath 1995; Kaptein 1993; Katz 2007; Knappert 1988; Muneer 2015; Salakidis 2018). The present study explores the context of the presumed earliest Arabic mawlid text from Malabar and thereby an example of synchronic intra-religious contact. Taking mawlid as both a literary and liturgical genre, I examine an intra-religious ritual transfer into a new setting, namely the transfer of mawlid writing and performance as it was practiced in different parts of the Arab world, encompassing Andalusia, North Africa, Egypt, Syria, Iraq, and the Arab Peninsula, to the Malabar Coast in South India, where the presumed earliest Arabic mawlid text was composed in the early sixteenth century.

Research on the Arabic mawlid so far has explored mainly the political and social context of mawlid celebrations, and much less attention was paid to the aesthetic forms connected to these celebrations. Even less is known on mawlid compositions from South Asia. Annemarie Schimmel, one of the few scholars in Islamic Studies to include South Asian literatures, seems to have been unaware of the Arabic mawlid texts written in India, since she describes mawlid literature in India as a late and primarily Persian-speaking development. ${ }^{1}$ Yet in my research on Arabic mawlid texts, I documented at least fifteen Arabic texts from South India. This paper seeks to explore the possible routes and channels of mawlid transfer and situate the presumed earliest mawlid text from South India into the wider tradition of Arabic mawlid compositions. Judging by the current state of research, hardly anything is known about mawlid practices in Malabar before the sixteenth century. The Arab traveller Ibn Battūta (d. 1368 or 1377), whose report on Malabar covers the 1340s, does not mention any mawlid ceremonies in Malabar (Ibn Batțūta 1879, 4:71-111). ${ }^{2}$ Likewise, the most recent study on Islam in Malabar (Prange 2018) makes no mention of any mawlid practices. Hence, it is the mawlid texts themselves that form our main source to investigate the advent of the mawlid genre in Malabar. This situation requires a twofold approach. First, I seek to identify mawlid books and mawlid authors that moved between the Arab lands and the Malabar Coast; and second, I examine the literary features of mawlid texts, addressing the question what a mawlid text is and how it works as a devotional practice. I argue that mawlid texts with a specific structure and style that was appropriate for liturgical reading formed a model for what is believed to be the first Arabic mawlid composition in Malabar.

As a first step into exploring Arabic mawlid texts in the South Indian context, the present study will focus on the Malabar Coast. Malabar as a region refers roughly to the southern West Coast of India, from Goa to Kanyakumari. Today, it belongs to the state of Kerala in South India. As a case study, I take two outstandingly popular Arabic mawlid texts, one from the Islamic West and one from Malabar. The first is Sharaf al-anām, a mawlid text that most probably stems from thirteenth-century Andalusia and travelled widely. Sharaf al-anām was apparently known in Yemen in the late fifteenth/early sixteenth century and is included in compilations of devotional texts in Kerala, where it is still performed in our days (63 Waka mawlid n.d.; Muneer 2015). The second text is Manqūs Mawlid, which was most likely composed in Malabar in the early sixteenth century. The composition is generally ascribed to Zaynaddīn ibn

1 "In the Indian subcontinent, a maulid literature proper developed rather late and was written predominantly—at least as far as narrative poetry is concerned—in Persian" (Schimmel 1985, 156).

2 Ibn Batțūța, however, does mention a mawlid ceremony in Ifrīqiya under the reign of the Hafșids of Tunis; see Ibn Baț̣ūța (1879, 4:327). 
'Alī al-Ma'barī al-Malībārī (d. 1522) ${ }^{3}$ and constitutes one of the most popular mawlid texts in Kerala today (Arafath 2018; Muneer 2015). Furthermore, both texts are commonly a part of compilations of devotional texts, therefore calling for a comparative analysis of the nature of such compilations in the different cultural and historical settings. Sharaf al-anām was chosen because of its wide circulation and popularity. Manqūs Mawlid marks an important chapter in the history of Arabic literary production in Malabar because it is considered its earliest mawlid composition and it is traditionally linked to the Portuguese occupation. The examination of both texts shows that mawlid was known in Malabar prior to the sixteenth century, or, more precisely, Arabic mawlid texts were known, which clearly shows in Manqūs Mawlid. The composition of Manqūs Mawlid proved to be quite successful and, granted that it was the earliest composition, triggered several other Arabic mawlid compositions in the region (see examples in 63 Waka mawlid n.d.).

\section{Arabic and Islam across the Indian Ocean}

Islam in the Indian Ocean evolved in various frameworks. The most eminent is trade, more precisely maritime trade networks. In addition, networks by followers of the mystical path, or Sufis, emerged. Finally, migration played a major role in establishing Muslim communities, especially migration from South Arabian regions, most prominently from Hadramawt, but also the Tihama region facing the Red Sea (Ho 2006; Pearson 2011; Ricci 2016). Sure enough, such networks are not to be understood to operate separately but were often overlapping and intertwined.

Within these networks of trade, mysticism, and migration, there was another web at work, which Ronit Ricci has termed "literary networks" (Ricci 2016, 1-4). Researching Islam in South and Southeast Asia, she identifies the Arabic language as a major player, similar to the role Sanskrit had played in the centuries before (300-1300 CE):

In South and Southeast Asia both Sanskrit and Arabic have served, in closely parallel ways, as generative cultural nodes operating historically in conflated multilingual, diglossic, and "hyperglossic" environments. [...] For Muslims worldwide Arabic possesses a unique status among languages. It is considered the perfect tongue by which God's divine decrees were communicated to His Prophet. [...] The Muslims in South and Southeast Asia proved no exception in their reverence toward the Arabic language, as they set up institutions where it could be studied, adopted its script to their own languages, borrowed its religious terminology and everyday vocabulary, prayed in it, and embraced its literary and historical narratives and forms. As a result, when I consider an Islamic cosmopolitanism in these regions, Arabic features as one of its major elements. (Ricci 2016, 14)

Ricci has coined the term Arabic Cosmopolis for the Muslim cultures in South and Southeast Asia where Arabic was not only a player in language contact but a tool of religious contact and ritual transfer. With the Arabic Cosmopolis she expands upon the Sanskrit Cosmopolis, a concept developed by Sheldon Pollock in the course of several articles and his monograph The Language of Gods in the World of Men (2006) (see Ricci 2016, 13-20, on differences in the

3 Amer (2019) and az-Ziriklī (2002, 64) agree on the date of his death, however, az-Zirikli spells "alMallībārī”. On him commonly assumed as the author of Manqūṣ Mawlid, see Arafath (2018, 3-4, 24); Muneer (2015, 12-13). See also below on the author. 
social role of both languages, 14-15). Whereas Ricci focusses on Arabicised rather than Arabic literary culture, I intend to focus on Arabic texts that were adopted and re-appropriated by Muslims living in Malabar.

The present paper constitutes a first step in an attempt to contribute to emerging scholarship on Arabic literary production along the Malabar Coast and beyond to the eastern regions of the Indian Ocean Littoral. Yasser P.K. Arafath $(2018,7-8)$ states that only a few Arabic works from Malabar have been explored as sources for historiography, whereas a large part of Arabic writing from the fields of jurisprudence (fiqh), poetry (qașida), preaching and exhortation (khuțba, tadhkir) by local Malabar scholars virtually remained terra incognita in Indian Ocean historiography. The present study deals with mawlid, a composition narrating the birth of the prophet and designed for performance, thus constituting a genre that comes from the field of both poetry and liturgy. Mawlid has been marginalised twice in Arabic and Islamic Studies. ${ }^{4}$ Since mawlid and the practice to commemorate or celebrate the prophet's birthday does not belong to the obligatory core of Muslim ritual and emerged only a few centuries after the prophet's death, it was often considered a popular devotional practice and thereby as secondary, especially in early scholarship, which was searching for an Islamic 'essence' and for 'origins' (Graham 1983). Second, its study has been neglected because the emergence of mawlid as text and practice coincided with the period that was considered as a period of decline (inhițāt) in Arab culture and especially Arabic literature. ${ }^{5}$ As for the Malabar context, mawlid has likewise been excluded in studies on Malabar Muslim literary culture, a choice that was seemingly overshadowed by theological or, more often, ideological dispute on conformity and deviancy in Muslim ritual (Muneer 2015, 9).

The Malabar Coast shared features typical of other coastal regions in the Indian Ocean, such as the Swahili coast, the coast of Sri Lanka, or the Coromandel Coast, in being outward looking, international, and cosmopolitan. Moreover, its main export commodity, pepper, was a highly desired good in both Europe and China. The region thus was not only integrated into global trade, with Arab merchants as an important player, but became a destination for European merchant fleets in the early modern period.

The situation of Muslims in Malabar differed from Muslims in the North in various aspects. Though early Muslim-Hindu contacts in form of trade alliances are documented, Muslim influence did not exceed beyond the coastal region, and it is not before the thirteenth century that we can speak of a sizable Muslim permanent population (Pearson 2011, 330-31). Unlike the Muslim sultanates in the North, such as the Delhi Sultanate (since 1206) and the Mogul Empire (since 1526), which emerged as powerful geopolitical forces in the region, Muslims in Malabar never seized a territory. Malabar Muslims remained the subjects of Hindu rulers, in particular the Zamorin of Calicut who were praised as benevolent patrons of Muslims (e.g., Zaynaddīn II (Aḥmad Zayn ad-Dīn al-Ma'barī al-Malībārī) [1405] 1985, 206) and the Rajas of Kochi. In the period the present paper deals with, roughly from the thirteenth to the early sixteenth century, North India was ruled by Muslim dynasties which were largely Hanafì and Persianate, whereas coastal Muslims were Arabicised and Shāfi $\bar{i}^{6}{ }^{6}$

$4 \quad$ A notable exception is Marion Katz (2007, 2019), who is the first to draw our attention to the newly emerging texts on the prophet's nativity and their role in Muslim piety.

5 On the inhitāt paradigm in writing Arab cultural history, see the contributions in von Hees (2017). It goes without saying that the inhițăt paradigm does not hold true against a thorough study of the period's cultural production.

6 Arabicised and Persianate refers to the literary productions that have come down to us from both regions in the relevant period. On the process of the Shäficisation of the Malabar Coast, see Kooriadathodi (2016). 
The Malabar Muslim community comprised Muslims 'from outside' (paradesi), a heterogenous group of mainly Arabs from different regions as well as Persians and Turks, and local Mappila. This backdrop is of relevance for the assessment of literary networks, since it tackles a multi-religious and multi-lingual situation. ${ }^{7}$ The growth of the Muslim community was fostered by immigration from Hadramawt in the thirteenth century, which included many religious authorities, namely scholars and sayyids who trace their lineage back to the prophet (Ho 2006; Pearson 2011, 329). Furthermore, a change in long distance trading patterns from the end of the thirteenth century on caused social changes. The end of a direct route between Baghdad and Canton (Guangzhou) led to the rise of several port cities, and especially Calicut became a major trade node. As a result, the Muslim presence became more settled. Arab merchants who had only spent longer sojourns abroad or regularly travelled home for domestic affairs established permanent settlements (Pearson 2011, 322, 330-31).

With the advent of Vasco da Gama in Calicut in 1498, Portuguese-Muslim trade competition and wars started. Trade and travel became more difficult and dangerous but did not stop, and Muslims continued to perform the pilgrimage to Mecca and to study abroad (Kooriadathodi 2016, 209). In parallel, we witness a growth of local centres of learning, which deepened the Shāficisation of the region (Arafath 2018; Kooriadathodi 2016). Such stages in the development of Muslim communities in Malabar, which have been mainly analysed in terms of migration, socio-economic changes, and jurisprudence (Ho 2006; Kooriadathodi 2016; Prange 2018), become tangible in religious practices and literary production, which the present study aims to show with the example of mawlid.

I start my analysis with a brief introduction to the historical background of commemorating the prophet's birthday and outline the general literary features of a mawlid text. The main part of the paper provides an in-depth description of the structure, content, and selected stylistic devices of Sharaf al-anām and compares these to Manqūs Mawlid. This comparison is for demonstrating that Manqūs Mawlid follows the genre conventions of Sharaf al-anām and similar mawlid texts, especially in terms of form and style. This part furthermore offers a comparative analysis of devotional text compilations (majm $\bar{u}^{\prime} a$ ) from the Arab world and South Asia. The last part examines the social context of the emergence of Arabic mawlid composition in Malabar. The composition of Manqūs Mawlid is traditionally linked to the advent of Portuguese naval power and subsequent wars and threats. Such a link, I argue, draws upon transformations in the function of mawlid readings at that time, which had turned from the commemoration of the birth anniversary to more general functions and occasions. Special attention is furthermore paid to the role of language and language experience which might have contributed to the emergence of a new poetic religious genre in Malabar, the māla.

\section{The Context of mawlid Texts: A Very Short History}

The Arabic lexeme mawlid denotes either the event, place, or date of birth; it can furthermore denote the commemorative celebration of the birth, or the aesthetic forms related to such a commemorative event. For instance, in his description of Mecca, the Andalusian traveller

$7 \quad$ It is important to keep in mind that language communities were by no means congruent with religious communities. The Arab maritime network included Muslims and Arabic-speaking Jews, as the Cairo Geniza records document; in Malabar, Malayalam was the native tongue of Muslims and Hindus alike. On language contact in the frame of Jewish-Muslim-Hindu networks as attested by the Geniza letters, see Gamliel (2018); Lambourn (2014). 
Ibn Jubayr (d. 1217) clearly relates to the place of the prophet's birth and not to the date or celebration: "Another blessed site in the city is the birthplace of the prophet (mawlid an-nabi)" (Ibn Jubayr 1959, 91). In his lifetime-he visited Mecca in 1183/4 -, the place was opened for visitors on Mondays in the month $\mathrm{Rabi}^{`}$ al-awwal of the Islamic calendar, as the prophet was believed to be born on a Monday in Rabī al-awwal (Ibn Jubayr 1959, 92). Writing roughly at the same time, using the lexeme mawlid, the Egyptian official Ibn at-Tuwayr (d. 1220) refers to the time and the event in his description of ceremonies in Fatimid Cairo (Ibn at-Tuwayr 1992, 217). Arabic legal and historiographical texts use the term mawlid interchangeably for the date, anniversary, observation, or festive celebration, so that the meaning must be derived from its context each time. Mawlid is furthermore often used as the short form for mawlid annabi (the prophet's birth), and it is in this sense I will be using the term here. Throughout this article, only texts on the prophet Muhammad's birth are discussed. ${ }^{8}$

The terminology for text and event commemorating the prophet's birth furthermore varies locally. In contemporary Kerala, the term mawlūd, which in Arabic designates the newborn, is far more widespread than mawlid (Muneer 2015, 1-2, 10). In Bangladesh, milād (birth) is the common term; ${ }^{9}$ in Egypt, it is mülid (a variant of mawlid in the spoken language), and in Turkey mevlit, mevlût, or mevlüt (also with final /d/). All terms are derived from the same Arabic root, $w$-l-d (to give birth).

The practice of commemorating the prophet's birthday as a public event is a rather late development in the history of Islam. Judging by the current state of research, there is no linear development of a ritual practice termed "mawlid." 10 As Marion Katz $(2007,2019)$ rightfully points out, there are quite different ways of observing the anniversary of the prophet's birth. Any history of the practices connected to the prophet's birthday needs to take account of differences between the observance of the day, for instance by individual fasting, and various forms of the day's communal ritual elevation, furthermore between private and public celebrations, and between assemblies with and without the public reading of literary texts written on the occasion of his birth. For the purpose of the discussion in this paper, I list some basic developments in order to give the wider context of the texts under study.

Early forms of piety that might be of relevance for later mawlid practices are found in the Imāmì Shiite traditions of narratives on the birth of the prophet and his close relatives and in the observation of their birth anniversaries through fasting, almsgiving, and rejoicing. Such practices are mentioned by authors of the tenth and eleventh century, unfortunately with very little details (Katz 2007, 3-5). The Fatimids in Egypt introduced mawlid commemorations as a state-sponsored event to emphasise their legitimation as a ruling dynasty. They thus celebrated not only the birth of the prophet Muhammad, but also of his daughter Fătima, his

8 Today, the recitation of mawlid texts written for persons other than Muhammad is rare in the Arab world, although in some regions such as Egypt or Morocco, the anniversary of other members of the prophet's family or of local patrons is celebrated. In Shiite communities, the day of birth and day of death of the Imams are observed in addition, with a varying degree of festive activities. By far most of the Arabic mawid texts are on Muhammad. However, it is worth noting that within the Arabic mawlid text compilations from Kerala, a considerable number has been composed for other persons than the prophet, such as the Badr mawlid dedicated to those early Muslims who died in the battle of Badr in 624 (63 Waka mawlid kitab, n.d.; Mawlid kitab, n.d.).

9 The term mìlād was also used (alongside with mawlid) in Arabic writing from the thirteenth century onwards, especially in the Islamic West, e.g., by Ibn Khaldūn (d. 1378) or al-Fishtālī (d. 1621-2) (al-Fishtālī, n.d., 235; Ibn Khaldūn 1911, 2:40). In modern Arabic, there is the tendency to use milād for Christmas and mawlid for the prophet's birthday.

10 For early developments in celebrating the prophet's birthday, see Abū l-Fath (1995, 33-39); Kaptein (1993); Katz (2007, esp. 1-5); Shinar (1977, esp. 371-81). 
son-in-law 'Alī, of the ruling caliph, and in some years also of the prophet's grandchildren Hasan and Husayn. The introduction of the Fatimid mawlids can be dated roughly to the mid-eleventh century (Kaptein 1993, 23-24; Lev 1991, 146-47).

For the second half of the twelfth century, we have sporadic references to mawlid celebrations in Syria and Iraq. The observance of the prophet's birthday by a pious figure named 'Umar al-Mallā' in Mosul that was attended by members of the local elite constitutes a semiofficial type of celebration. It was marked by the recitation of poetry praising the prophet (Kaptein 1993, 35). There are furthermore indications for the observance of mawlid by the Zengid ruler Nūraddīn (d. 1174) in Aleppo (Kaptein 1993, 31-34). The huge celebrations on the occasion of the prophet's birthday organised by the Begteginid ruler Muzaffaraddin ( $\mathrm{r}$. 1190-1232) in Irbil are, in contrast to the events mentioned before, very well documented. The most famous description is included in the biographical dictionary by Ibn Khallikān (d. 1282), which allows us to date the yearly celebrations to the end of the twelfth/beginning of the thirteenth century [Ibn Khallikān (1990), 3:449-50; 4:117-19]. The celebrations span over a period of several weeks and included banquets, sermons, processions, recitations, the distribution of presents, and various forms of entertainment.

In the Muslim West, the 'Azafid rulers in Ceuta introduced mawlid celebrations in the first half of the thirteenth century; rulers of other local dynasties in North Africa and Andalusia followed from the mid-thirteenth century onwards (Brown 2014; Kaptein 1993, 76-140). As becomes clear from the sources analysed by Kaptein (1993) and Shinar (1977), the venues of mawlid festivities ranged from court celebrations to public places, Sufi lodgings, schools, and private homes. Besides the recitation of literary compositions written for the occasion, festivities included various elements of ritual (e.g., fasting, Quran recitation) and entertainment (e.g., horse racing, musical performances). Thus, by the late thirteenth century, the observance of the prophet's birthday had become a widely established practice marked by public celebrations on a wide scale and in different geographic regions.

It should be noted that this new occasion for celebration did not remain undisputed among Muslim scholars. Moreover, the answer to the question whether the celebration of mawlid was an approvable innovation or not was rarely a simple Yes or No (as today's dichotomic treatment of many subjects would suggest). Rather, it was often a conditional Yes, evaluating the different aspects and practices in observing the prophet's birthday separately. The tenor of many statements was that the observation of the day was not objected to, given the fact that it was observed to honour and thank God and the prophet and that it was not accompanied by any unlawful activities. To feed the poor or have the Quran recited on that day was deemed a meritorious act even by sceptical scholars like Ibn al-Hājj (d. 1336-37) or Ibn Taymīya (d. 1328). Both nevertheless expressed their reservation and feared people would understand the observation of the prophet's birthday as an obligatory duty or treat it like a canonical feast ('id). Mawlid frequently became an object of legal opinions (fatāwā, sg. fatwā), dealing with various aspects of its celebration, such as what gifts to bring or the legitimacy of including money for mawlid celebrations into a pious endowment (waqf). An often-quoted classic is the lengthy fatwā by the Egyptian polymath Jalāladdīn 'Abdarraḥmān as-Suyūṭī (d. 1505), who discusses the pros and cons by many other scholars before giving his conditional licence. ${ }^{11}$

11 Ibn Taymīya (n.d., 2:618-24); Ibn al-Ḥājj (n.d., 2:2-32); as-Suyūṭī (1985); furthermore Kaptein (1993, 112-15, 123-24, 135-37); Katz (2007, 104-42, 169-207); Ukeles (2010). 


\section{Mawlid as a Transcultural Genre}

Roughly at the same time when the practice of observing mawlid in public celebrations on a wide scale developed, a new type of text emerged in the Arabic-speaking world whose literary features persisted until the twentieth century. These texts centre on the birth of the prophet Muhammad and the occurrences which preceded, accompanied, and followed his birth: the various signs that happened during pregnancy and birth, the search for a wet-nurse, and episodes from his childhood and youth. On a formal level, the texts combine prose, rhymed prose, and poetry. Today's prints of the most popular texts have approximately 40 pages, which means they can be easily recited in one session. Such texts seem to form a literary genre whose name is taken from the main event they describe: the birth of the prophet, i.e. mawlid.

Katz $(2007,2019)$ is right to emphasise that texts that describe the birth and life of the prophet precede the communal public mawlid celebrations. However, the specific textual genre I am describing here emerged when celebrating the prophet's birth became established on a wide scale. The newly emerging mawlid texts do not differ much in content from the preceding ones, but rather in form, and these formal characteristics allow us to speak of these texts as a genre of its own (Katz 2007, 50, 2019, 168).

The mawlid genre, to my mind, offers a rich perspective for exploring the transcultural circulation of Arabic texts and the religious practices connected to these texts. This genre soon spread beyond the Arabic-speaking world, where mawlid texts became recited and composed in Arabic as well as other languages. First, we find Arabic texts from the Western and Eastern Arab regions recited outside the Arabic-speaking world: the text Sharaf al-anamm is widely used in South India (Kerala)—but also in Malaysia, Indonesia, Kenya, Tanzania, or Somalia (Knappert 1988; Muneer 2015; evidence by manuscripts from different regions, see n. 14). Thus, Sharaf al-anām can certainly be termed a "traveling text." Since the late nineteenth century, it also travelled as a book in print: Jan Knappert $(1988,212)$ notes its first edition was printed in c. 1885 by the publishing house of a certain Sulaymān $\operatorname{Mar}^{\prime} \overline{1}$ located in both Singapore and Aden.

Second, we find translations from Arabic into other languages: for instance, the mawlid composed by the Shāfi ${ }^{\prime} \overline{~ m u f t i ~ o f ~ M e d i n a, ~ J a ' f a r ~ i b n ~ H a s a n ~ a l-B a r z a n j i ̄ i ~(d . ~ 1764), ~ h a s ~ b e e n ~}$ translated into Indonesian and Malay languages (Knappert 1988, 213). Third, mawlid texts were newly composed in Arabic outside the Arab world, for instance by Malabar Muslims in Kerala: The Manqūṣ Mawlid, generally ascribed to Zaynaddīn ibn 'Alī al-Ma'barī al-Malībārī, serves as a prominent example. This case in point constitutes an example for a "traveling genre." Forth, mawlids have been composed in other languages, such as the famous mawlid in Ottoman Turkish by Süleyman Çelebi (d. 1421) ${ }^{12}$. Hence, the mawlid is a highly transcultural phenomenon that moves between different regions and languages.

\section{Mawlid as a Text: Structure and Formal Characteristics}

The following brief characterisation of mawlid texts draws from the evaluation of a sample of about 30 mawlid texts which were composed between the thirteenth and eighteenth century and which cover a geographical span from Andalusia in the West to Yemen in the East. Only a

12 The formal structure of Çelebi's mawlid, which is written entirely in couplets, differs from the texts discussed here; its function, nevertheless, is confluent to the functions that will be discussed here. For Çelebi's text, see, with further references, Salakidis (2018, esp. 344-47). 
small number of mawlid texts is available in scholarly editions; rather, texts mainly circulate in inexpensive leaflets. For my research on formal characteristics, I heavily rely on manuscripts. The evaluated texts share several common features which will be briefly summarised.

A mawlid text is usually prosimetric, that is, it combines poetry and prose, as many premodern texts in Arabic literature do. A strict separation of genres written entirely either in verse or in prose did not prevail before the nineteenth century (Heinrichs 1997, 249; Reynolds 1997, 277). The Arabic language furthermore knows a third mode of speech, termed $\operatorname{saj}^{`}$. Saj', generally translated as "rhymed prose," designates speech units of different length with no metre, but with a rhyme at the end. All three modes, poetry, prose, and $s^{j} j^{c}$, are combined in Arabic mawlid texts.

A mawlid text contains several episodes from the life of the prophet, framed by an introduction and a concluding supplication $\left(d u^{(} \bar{a}^{\prime}\right)$. The introduction usually is in highly ornate speech, featuring praise of God and successively of Muhammad. The single episodes on the prophet's life are often preceded by reports on God's creation and/or the prophet's genealogy. The focus of mawlid texts lies on Muhammad's birth and episodes from childhood and youth. Many texts end here, and if they go further, they only briefly mention events that happened after the prophet's first marriage with Khadija (see also Katz 2007, 55). A great part of the poems figure praise of the prophet; in addition, a considerable number of poems is interwoven into the narrative line, featuring the prophet's grandfather as a speaker or addressing his mother Āmina.

Poems are rarely longer than 20 lines, and occasionally only two or three verses are inserted into the text. Much of the poetry is in the qasidda form with a mono-rhyme (on qașida, see also below). A considerable amount of poetry, though, is in strophic forms (muwashshah, mukhammas), which are apt for singing, or poems provide different types of refrains by which listeners are able join a solo performer. In addition, texts repeatedly feature an invocation of blessing for the prophet (tasliya) which may take on an embellished form in rhyming couplets or quatrains.

Though all examined texts share this general structure, there are also differences. Mawlid texts vary in length, in the amount of poetry used, and in the density of the rhetoric devices that are employed to beautify the text. Some texts contain long passages in plain prose; other texts are careful literary compositions with only a minimum of non-ornate prose. Mawlid texts also vary in content: some texts show close conformity with the scholarly established biography of the prophet (sira) ${ }^{13}$ and build on material from the Quran and Hadith. Other texts include motifs and reports that circulated outside of these sources and are in parts present in later compilations on the prophet's extraordinary qualities and the signs of his prophethood (i.e., books on khașāiss, shamā'il, and dalä'il). ${ }^{14}$ In addition, some authors added lengthy explanatory passages on single motifs or events into the narrative. Further literary features of a mawlid text shall be exemplified through the example of a highly popular text: the abovementioned Sharaf al-anām.

13 The biography of the prophet had been compiled during the first centuries after the prophet's death. The text that gained the most authority can be traced back to Ibn Ishāq (d. 767) and is preserved in the redaction by Ibn Hishām (d. 834). Ibn Hishām ([1937] 1955).

14 On the content of mawlid texts, see Katz (2007, 6-72). Typical works that collect a wide array of aspects on the prophet's behaviour, deeds, sayings, physical outlook, and character are, for example, Ibn al-Jawzī (n.d.); al-Qāḍi 'Iyāḍ (n.d.). Books on the prophet's life and qualities that may have served as sources for mawlid texts have furthermore been compiled, inter alia, by authors like Abū Nu'aym al-Ișbahānī (st. 1038/39), al-Bayhaqī (d. 1066), Ibn Sayyid an-Nās (d. 1334), al-Qasțallānī (d. 1517), or as-Suhaylī (d. 1185). 


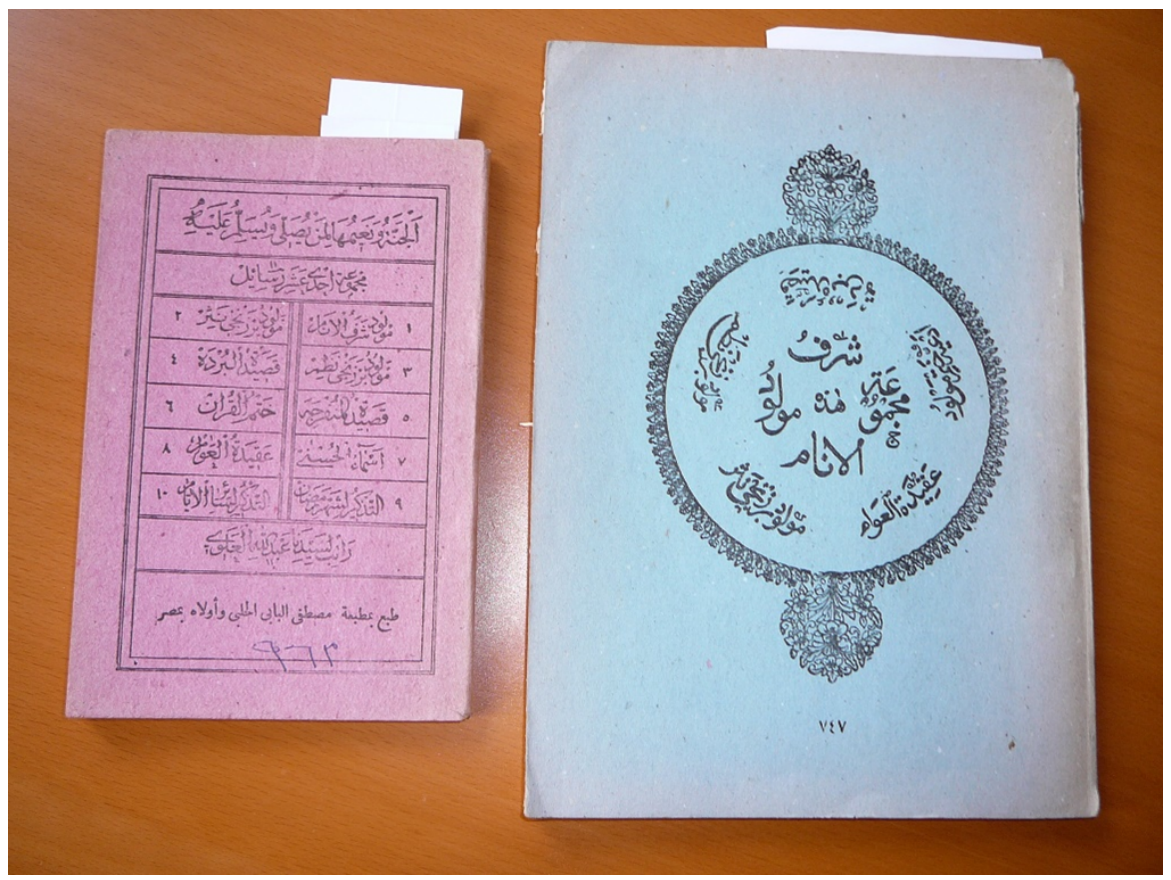

Figure 1 Title page of compilations of devotional texts including Sharaf al-anām. The book on the left was printed in Cairo (Majmǘ $a t$ rasä'il, = example No. 1), the book on the right bears no printing place (Majmü'at Sharaf al-anām).

\section{Sharaf al-anām: General Introduction to the Text}

Sharaf al-anām takes its title from the opening line of the text's introduction, a practice that we find with other mawlid texts as well. The opening line goes:

الحمدُ لله الذي شرّف الأنامَ بصاحب المقام الأعلى

al-Hamdu li-llāhi lladhì sharrafa l-anāma bi-șāhibi l-maqāmi l-a lā *

Praise be to God who honoured humankind with the possessor of the highest station *

We find the title under two different readings that the written Arabic allows without further diacritic marks: it is either read as a summarising nominalisation (Sharaf al-anām: The Honour of Humankind), or as a direct quote from the introduction's opening line (Sharrafa l-anām: He Honoured Humankind). In any case, in most versions of the text, the introduction is preceded by a long salutation to the prophet (salām) and a few quotations from the Quran (verses 48: 1-3; 9: 128-129; 33:56), interspersed with praise and the invocation of blessings. ${ }^{15}$

For the majority of the mawlid texts, the authors are well known. Nevertheless, there are cases, and some of the most popular texts are included in these cases, where the author is

15 Majmū'at Sharaf al-anām (Majmū'at iḥ dā 'ashara rasā’il, n.d., 1-71); Majmū'at rasā’il (Majmū'at Sharaf alanām, n.d., 2-48); Abū l-Fath (1995, 3:255-67); al-Barzanjī et al. (2008, 51-100); 63 Waka mawlid (63 Waka mawlid kitab, n.d., 2-28). This also applies to the manuscripts I have been able to examine so far (King Saud University 5971, 4/1734F, starting f. 47r; British Library Or 16873 (from Java); British Library EAP609-5-4 (from Sri Lanka); British Library EAP466/1/18 (from Kenya), starting tiff no. 133 (no folio numbers), without the Quranic quotations). In the following, page numbers for Sharaf al-anām refer to the text in al-Barzanjī et al. (2008) if not indicated otherwise. 
not known, or the authorship is contested. This is the case with Sharaf al-anäm. The Yemeni scholar Ibn ad-Dayba' (d. 1537) claims to have identified a certain Shihābaddīn Aḥmad ibn 'Alī ibn Qāsim al-Māliki al-Bukhārī al-Andalusī al-Mursī al-Lakhmī, known as al-Ḥarīrī, as the author of Sharaf al-anām. This incident is reported by 'Abdalqādir ibn Shaykh ibn 'Abdallāh al-'Aydarūs (d. 1628), a member of a prominent Hadrami family that moved to Gujarat (al-Aydarūs 2001, 292). ${ }^{16}$ Ibn ad-Dayba's attribution is supported by the eighteenth-century author Fatḥallāh al-Bannānī, who names a person with an almost identical name: Abū l-'Abbās Aḥmad ibn Qāsim al-Mālikī al-Bukhārī al-Andalusī al-Lakhmī, known as al-Ḥarīrī. Nevertheless, such a figure has not been identified yet in the biographical lexica (Katz 2007, 52). From the scarce information available, Katz concludes that the work ...

[...] can be traced to an Andalusian Mālikī. If al-Bannānī is correct in describing him as having moved from Bukhara to Murcia (al-bukhārì thumma 'l-mursī), he is unlikely to have done so later than the mid-seventh-century AH/thirteenth-century $\mathrm{CE}$, when the latter city fell to the Christians. Certainly there must have been time for the work to become widely popular - and its true authorship to be obscured - by Ibn al-Dayba's lifetime in the first-half of the tenth-century AH/sixteenthcentury CE. (Katz 2007, 52-53)

Identifying the authors of very popular early texts is indeed difficult because of the high fluidity of such texts. It was common to borrow text passages or to include lengthy material from Hadith and sira works without necessarily indicating the source. It was also not uncommon to ascribe texts to renowned scholars (Katz 2007, 59-60). Today, the text of Sharaf al-anām appears in numerous forms and prints. To complicate matters, we rarely find Sharaf al-anām as a stand-alone text, but it is commonly integrated into a collection or compilation (Arab. $m a j m \bar{u}(a)$ of other devotional texts which features under the same title, i.e., Sharaf al-anām. Sometimes, such a compilation is named Mawlid al-Barzanjī, since al-Barzanjī's text often is included as well. ${ }^{17}$ I will demonstrate the common features of such compilations through selected examples from the Arab world and South Asia.

\section{Mawlid as Part of a Compilation (majmü $\left.\bar{u}^{c} a\right)$ of Devotional Texts}

To compile more than one text into a single manuscript was a common phenomenon in the Arabic-Islamic tradition of learning. The majmü $a$, thus, is by no means a modern phenomenon or limited to printed books. Gerhard Endress (2016) differentiates between composite manuscripts which originally had been separate codicological units that later were bound by a bookseller or librarian and multiple-text compilations that had been written and organised by one scribe. Both are called majmü' $a$ ("collected") in Arabic, and the texts included in such a majmü' $a$ can comprise quite different fields of knowledge. Likewise, the practice to

16 'Abdalqādir ibn Shaykh spent most of his life in Ahmadabad. The 'Aydarūs lineage belongs to the Bā 'Alawī kinship group from Hadramawt, who trace their lineage to the prophet. The most extensive work on the 'Aydarūs lineage is Peskes (2005); see also Ho (2006, esp. 110-12, 116-37).

17 For instance, Majmū'at Sharaf al-anām (Majmū' $a t$ Sharaf al-anām, n.d.) starts with Sharaf al-anām, followed by Barzanjī's text; al-Barzanjī et al. (2008) equally starts with Sharaf al-anām, followed by al-Barzanjī's text, but is titled after al-Barzanjī. It should be noted furthermore that al-Barzanjī wrote two mawlid texts, one of them entirely in verse. Commonly, both texts are included in the collections. Knappert $(1988,212)$ seems to assume that Sharaf al-anām is identical with mawlid al-Barzanjī, or the collection he describes does not contain the Sharaf al-anām text, although it bears the title Sharaf al-anām. 


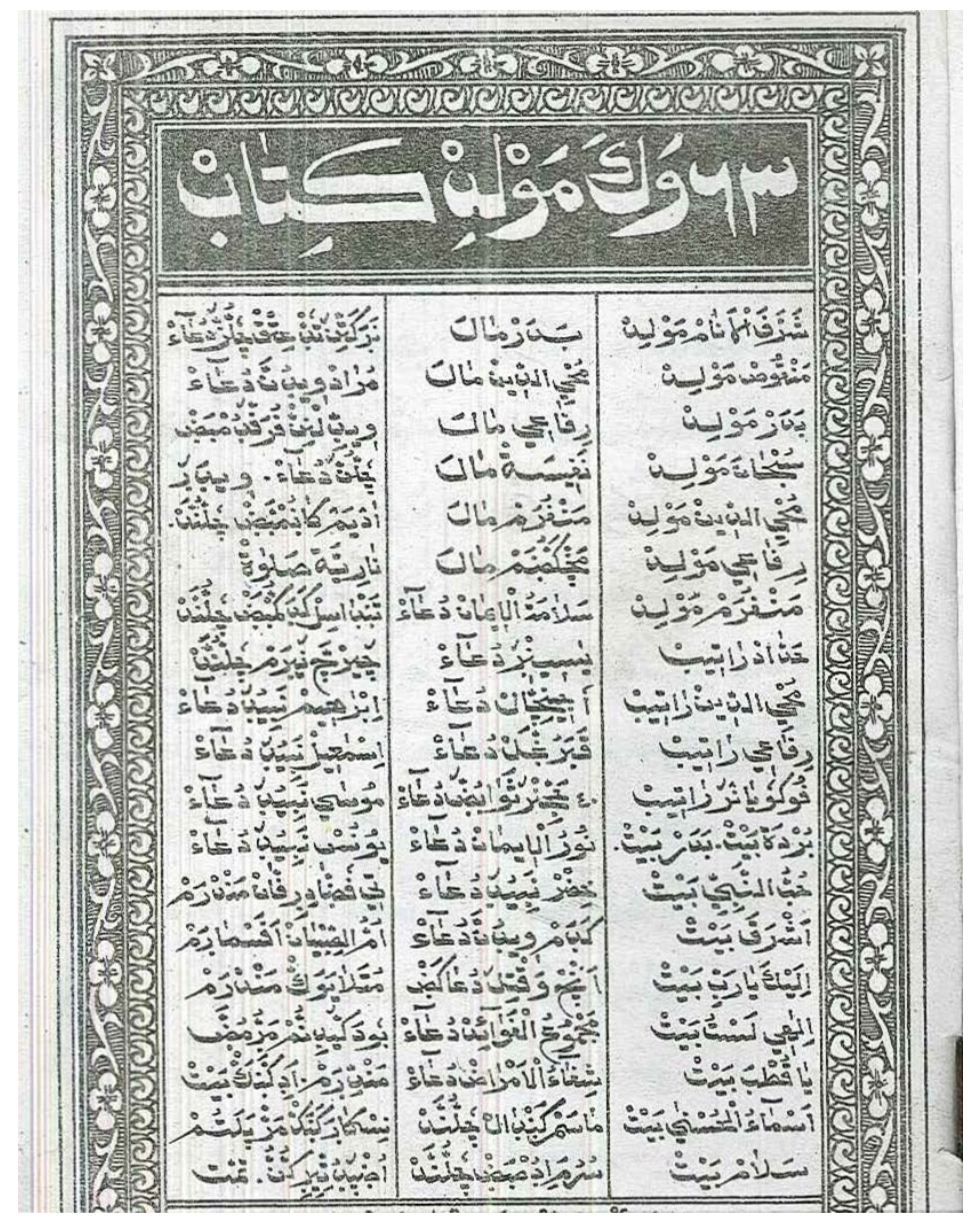

Figure 2 Title of content of a compilation from Thirurangady, Kerala (= example No. 3).

organise different devotional texts into one manuscript or print includes other genres besides the mawlid. In the following, I will present the content of some contemporary compilations from West and South Asia. In a number of these, the title page has the function of a 'table of contents', as it announces the different texts included into the book: Illustration 1 shows the title of a compilation from Cairo (left, this is example No. 1 in Table 1 below) and a second one without printing place (right). Though different from the outlook, the content of both books is almost identical. Figure 2 shows the content of a compilation from Thirurangday, Kerala (example No. 3 in Table 1 below).

Table 1 shows the content of three selected compilations in a table. The first example is an undated print from Cairo that, by name of the publisher and visual appearance, can be dated roughly to the first half of the twentieth century (Majmü'at ihda ' $a s h a r a ~ r a s \bar{a}$ 'il, n.d.). ${ }^{18}$ The second one was compiled by a private person and uploaded as a pdf file on the internet (Mawlid kitab, n.d., see also below). It contains only Arabic texts, but additional information is given in Malayalam, which indicates a Kerala provenience. The third example was printed in Thirurangady, Kerala, and contains devotional texts in both Arabic and Arabic Malayalam

18 The publisher's name is given as Mușțafā al-Bābī al-Ḥalabī wa-Awlāduhu bi-Miṣr. The well-known publishing house of the al-Bābī al-Halabī family was founded in 1859 by Aḥmad al-Bābī al-Ḥalabī. In 1919, two of his nephews started their own company under the name Muṣțafā al-Bābī al-Ḥalabī wa-awlāduhu bi-Miṣr. Since this company was later renamed by Muștafā's son or grandson (Winkler 1997, 41), the publisher's name Muștafā al-Bābī al-Ḥalabī wa-Awlāduh bi-Miṣr indicates that the booklet was printed between 1919 and roughly the 1950s, that is, before the company was renamed. 
(63 Waka mawlid kitab, n.d.). ${ }^{19}$ All three compilations prominently feature the mawlid text Sharaf al-anām.

Table 1 Compilations from the Arab world and from Kerala that feature Sharaf al-anām.

\begin{tabular}{|c|c|c|}
\hline Majmü'at rasā'il (No 1) & Mawlid kitāb (No 2) & 63 Waka mawlid (No 3) \\
\hline Sharaf al-anām & Yā akram bayt & Sharrafa l-anām mawlid \\
\hline Mawlid al-Barzanjī (both) & Sharaf al-anām mawlid & Manqūṣ Mawlid \\
\hline Qașidat al-Burda & Manqūṣ Mawlid & $\begin{array}{l}\text { More mawlid texts from } \\
\text { South India }\end{array}$ \\
\hline More poems & Mawlid Badr & $\begin{array}{l}\text { Several rātib texts, } \\
\text { including Ḥaddād }\end{array}$ \\
\hline Khatm al-Qur'ān & Qașidat al-Burda & Burda bayt \\
\hline Prayers and litanies & Poem praising Khadīja & More Arabic poems (bayt) \\
\hline Rātib 'Abdallāh al-'Alawī & & Several māla texts \\
\hline
\end{tabular}

al-Haddād

Several $d u^{c} \bar{a}^{\prime}$

What are the other texts that are typically combined in such compilations? Yã akram bayt is the last part (vv. 152-160) of the Mantle Ode (Qașidat al-Burda), an ode in praise of the prophet Muhammad composed by the Egyptian poet Sharafaddīn Muhammad al-Būṣīīi (d. 1294-97). According to tradition, the poet, after composing and reciting the ode in order to seek the prophet's intercession and God's forgiveness, fell asleep and saw the prophet in his dream, covering him with his mantle (burda). Thus, the ode was called Mantle Ode, or Burda. The title Yã akram bayt is derived from verse 152 that starts with Yã akrama r-rusli (Oh best of [all] prophets), addressing Muhammad (1955, 200-201). ${ }^{20}$ The Mantle Ode was already famous for its assumed auspicious power during the lifetime of the poet, and it features in numerous compilations of devotional texts as well as in stand-alone prints and manuscripts. The opening verses of example No. 2 are combined with a seven-verse prayer that is commonly added to the performance of the Burda. ${ }^{21}$ The complete Burda poem is included in all three compilations.

The Arabic term qașida can denote any poem in a general sense. Yet, qașida is also the technical term for a type of poetry that needs to meet certain formal criteria. In this narrower sense, qașida designates a polythematic, non-strophic poem with mono-rhyme and in one of the 16 metres codified as 'classical.'22 This type of poetry is documented from the sixth century onwards and is still composed today. It is also the main form of praise poetry for the prophet Muhammad (al-madị an-nabawi), the Burda being one of its most prominent examples. Bayt in Arabic denotes a poem's single line, which in the qasida form consists of two hemistichs. In the South Indian context, the Muslim Arabic poetry that builds on the

19 I am indebted to Ophira Gamliel for drawing my attention to this book and for deciphering its title and publication place as well as for spending some illuminating hours with me reading into selected mawlid and māla texts together.

20 Another version of the verse is Yã akrama l-khalqi (O best of [all] creation), which is found in 63 Waka mawlid (63 Waka mawlid kitab, n.d., 129) and Mawlid kitāb (Mawlid kitab, n.d., 68), and occasionally in Burda performances Lebanon (Weinrich 2016, 110).

21 See Weinrich (2016) on the earliest traditions related to the poem, 107-08; on the prayer, esp. 116-17.

22 The codification of Arabic metres goes back to Khalīl ibn Ahmad (d. c. 970). For a short introduction to Arabic rhyme and metre, see van Gelder (2012, 341-65). 
formal features of Arabic poetry is called bayt. In our examples from Kerala, bayt and qasiida are used interchangeably: in example No. 2, the complete Burda is termed Qașidat al-Burda, whereas in example No. 3, it is termed Burda bayt.

Example No. 3 includes a second poetic genre, the māla. Māla is the technical term for poetry composed in Arabic Malayalam and dedicated to eminent Muslim figures (on māla, see also below). Arabic Malayalam, that is, Malayalam written in an adopted Arabic script, can be traced to the early seventeenth century, the famous Muhyiddin Mãla composed by the Shāfiīi scholar Qāḍī Muhammad (d. 1616) (Arafath 2020, 2) being its most prominent example. The Muhyìddīn Māla is a long poem in praise of the Hanbalī scholar 'Abdalqādir al-Jīlānī (d. 1166) who is venerated as a Sufi and reviver (muhyī) of religion. Composed in 1607 , it is generally considered the first written evidence of this language amalgamation and combines the Arabic poetic tradition with polyglossic Malayalam and the Dravidian literary tradition (Arafath 2020; Gamliel 2017).

Khatm al-Qur'ān, which features in example No. 1 , is a type of prayer $\left(d u^{(} \bar{a}^{\prime}\right)$ performed after the complete recitation of the Quran. In contrast to the ritual prayer (salät), which in its prescribed liturgical form comprises various verbal and bodily acts, the performance of $d u^{(} \bar{a}^{\prime}$ is without prescriptions in terms of time, text, or body movements. Texts may be chosen from the Quran, from the prophet's example, or individually composed. Rātib either denotes supererogatory ritual prayer (șalāt) or, here, litanies recited alone or in groups. Rātib 'Abdallāh al-'Alawi al-Haddād thus is a litany ascribed to 'Abdallāh al-'Alawī al-Haddād (d. 1720), a Sufi poet from Yemen. ${ }^{23}$ Example No. 3 includes rātib 'Abdallāh al-'Alawì al-Haddād, too, as well as several other rātib texts ascribed to prominent Muslim scholars.

Plentiful Arabic compilations that I have documented in the course of my research are similar to the described examples. For the Southeast Asian context, two other compilations described in the research literature can be added here. The text of Sharaf al-anām that Nawwāl Abū l-Fath (1995) used for her study is a reprint from a compilation published in Jakarta. Besides Sharaf al-anām, it includes both mawlid texts of al-Barzanjī, the mawlid by the aforementioned Ibn ad-Dayba', the mawlid by the nineteenth-century scholar from Medina, Muhammad ibn Muhammad al-'Azab (GAL S II, 815), the Mantle Ode by al-Būṣīīi, and several prayers, including one to be recited after a mawlid and one to be recited after the complete recitation of the Quran (Abū 1-Fath 1995, 2:255). The content of the aforementioned compilation from Singapore and Aden as given by Knappert (1988, 212-13) comprises both mawlid texts by al-Barzanjī, the Mantle Ode by al-Būsīini, a prayer $\left(d u^{(} \bar{a}^{\prime}\right)$ to be read after a mawlid recitation, another one to be recited in the Mid-Sha'bān night, ${ }^{24}$ and two condensed versions of the main Muslim doctrines. Thus, the typical genres included in such compilations that feature Sharaf al-anām are, next to mawlid, praise poetry (qașida, bayt, māla), litanies (rātib), and prayers, most typically prayers that conclude the recitation of mawlid or the Quran.

Such compilations of devotional texts were printed in publishing houses like the one founded by the al-Bābī al-Halabì family in Cairo in 1859 and specialised in publishing the Arab-Islamic heritage. Moreover, compilations as well as single mawlid texts were often printed on behalf of and financed by individuals. A considerable number of texts that I col-

23 On him, see Alatas (2014). He is a member of the Bā 'Alawì kinship group that has been based in Hadramawt and migrated to regions around the Indian Ocean.

24 This night of the eighth month of the Islamic calendar, Sha'bān, is believed to be a special time of the year. According to some prophetic traditions, God descends on this night to the lowest heaven to answer the believers' prayers. Additionally, some scholars, with reference to Q 44:2-4, see this night as the one where it is decided who will die in the year to come (Kister 1979, 24-25). 
lected and a large number of texts included in Abū l-Fath's study bear such an indication, usually in the form of a short notice on the cover or the back of the print. To compile and/or finance the print of devotional texts is considered a religiously meritorious act. We can conclude that the texts gathered in such collections were either popular and in demand or considered as useful by a single person. A recent example is the compilation of mawlid texts and poems that has been uploaded on the internet as a pdf file (example No. 2). The compiler expresses his hope that somebody would put it into print (Mawlid kitab, n.d., 72). ${ }^{25}$

\section{Sharaf al-anām: Content and Structure}

To give an idea of the text's structure, I will show the first episodes of Sharaf al-anām and their respective forms (prose, $s a j$, , or verse) in a simplified form in a table:

Table 2 The first pages of Sharaf al-anām.

\begin{tabular}{|c|c|c|}
\hline Content (topic in brackets) & Form & $\begin{array}{l}\text { Number of } \\
\text { pages }\end{array}$ \\
\hline Salutation & verse & $5 \mathrm{pp}$ \\
\hline $\begin{array}{l}\text { Quranic verses, praise, invocation of } \\
\text { blessings }\end{array}$ & $\operatorname{saj}^{c}$ & $1 \mathrm{p}$ \\
\hline $\begin{array}{l}\text { Introduction } \\
\text { (Doxology, synopsis) }\end{array}$ & $\operatorname{saj}^{c}$ & $1 \mathrm{p}$ \\
\hline Poem & verse & $1 \mathrm{p}$. \\
\hline $\begin{array}{l}\text { Quranic verses and explanatory } \\
\text { passages }\end{array}$ & & $1 \mathrm{p}$. \\
\hline $\begin{array}{l}\text { Episode starting with Hadith } \\
\text { (Pre-existing light) }\end{array}$ & prose, passage in $s^{c} j^{c}$ & $1 \mathrm{p}$. \\
\hline Poem & verse & $1 \mathrm{p}$. \\
\hline $\begin{array}{l}\text { Episode narrated by Yazīd ibn } \\
\text { 'Abdallāh ibn Wahb, } \\
\text { then narrated by Āmina } \\
\text { (Realising pregnancy) }\end{array}$ & prose & $1 \mathrm{p}$. \\
\hline $\begin{array}{l}\text { Unnamed Narrator } \\
\text { (Creation of the prophets) }\end{array}$ & $\begin{array}{l}\text { starts in prose, changes to } \\
\text { saj }^{c}\end{array}$ & $1.5 \mathrm{pp}$ \\
\hline $\begin{array}{l}\text { Auctorial Narrator } \\
\text { (Nine prophets visit Āmina) }\end{array}$ & $\operatorname{saj}^{\varsigma}$ & $1.5 \mathrm{pp}$ \\
\hline Poem & verse & $1.5 \mathrm{pp}$ \\
\hline
\end{tabular}

From this short overview, two main characteristics become obvious. First, the text swiftly switches between poetry, prose, and saj ${ }^{\dagger}$. Sometimes, prose and $s a j{ }^{`}$ are used in the same paragraph. Second, the narrative perspective changes frequently. We also encounter different types of texts, such as narrative passages, quotations from the Quran, short explanatory passages (e.g., to Quranic verses), prayers, praise in ornate speech, and poetry.

The narrative passages are either introduced by an unknown narrator, sometimes indicated

25 Thanks is due to Ophira Gamliel for translating the relevant passage in Malayalam for me. 
by the passive voice- "it is said (qill)" -, or the person who transmitted what is said is named, here for instance Yazīd ibn 'Abdallāh ibn Wahb, a nephew of Āmina. Āmina, Muhammad's mother, then narrates from the first-person perspective. Later, large parts of the text are narrated from the perspective of Halima, the prophet's wet-nurse. I will show the rest of the text in a less detailed manner in order to get an overview of its content.

Table 3 Further content alignment in Sharaf al-anām (An open line indicates the place of a poem).

Birth, description of the baby, the world's reaction to the birth

Āmina watches the baby

Episode narrated by Muḥammad ibn Sacd, then Āmina: Birth and lights

Episode narrated by Yazīd ibn 'Abd Allāh ibn Wahb, then

Āmina:

Grandfather is informed about the birth

Praise, heavenly figures pay their respect to the baby

Salutation

Occurrences during birth, partly repetitions in content

Episode narrated by ahl as-siyar, ${ }^{26}$ then Halīma:

Draught; her tribe leaves for Mecca;

women look for infants to breastfeed

Halìma continues to narrate:

Halìma meets the grandfather

Halìma continues to narrate:

Halīma meets Âmina and the baby; Halīma recovers from hunger

Halìma continues to narrate:

Halìma visits the Kaaba; returns home;

nature recovers from the draught

Halìma continues to narrate:

Episode of purification (shaqq aș-ṣadr, lit. breast opening)

Praise, mentioning the prophet's night journey (al-isrā')

Episode narrated by 'Abdalwāhid ibn Ismā'̄̄ll:

Jewish couple in Egypt watch their neighbours

celebrating mawlid

and, after encountering Muhammad in a dream, convert

to Islam $\operatorname{saj}^{c}$

saj $^{c}$

prose, short passage in $s a j^{c}$

saj $^{c}$

verse

saj $^{c}$

prose, short passage in $s a j^{c}$

prose

prose, short passages in $s a j^{c}$

prose

prose, short passages in $s a j^{c}$

$\operatorname{saj}^{c}$

prose, $s a j$ ', and poetry 
Table 3 Further content alignment in Sharaf al-anām (An open line indicates the place of a poem).

The last episode on the Jewish couple constitutes a shift in the time axis, since it reports on a celebration of the prophet's birthday that took place much later than during the prophet's lifetime. It seems that the episode circulated independently and was included in several texts, which we will come back to later. The episode of purification (shaqq as-șadr), in which two men appear, open the little boy's breast—in other versions his belly (batn)—and take out his heart and wash it, is included in many other mawlid texts and also in the sira (Ibn Hishām [1937] 1955, 164-65). The prophet's night journey (al-isrā') is only alluded to in the text of Sharaf al-anām. al-Isrā' denotes a nightly journey from Mecca to a "furthest place of worship (al-masjid al-aqșā)" (Q 17:1), which is either interpreted as a place near Mecca, Jerusalem, or a heavenly place (Neuwirth 2010; Rubin 2008).

In general, the outline of its content shows that Sharaf al-anām is not a linear narration. There are repetitions of the same events narrated in different versions and sometimes also from different perspectives. Especially the occurrences during the prophet's birth are described more than once. Furthermore, the narration is selective; some important events are not mentioned, for instance the revelation of the Quran. In contrast, the text contains events that are not found in the scholarly authorised biography of the prophet, such as the prophets' visits during Āmina's pregnancy. Sharaf al-anām shows the composition technique of compiling reports from different sources and adding an introduction and poetry. In the following, I will demonstrate some stylistic devices in more detail that are relevant for a comparative analysis.

\section{Sharaf al-anām: Selected Aesthetic Features}

Sharaf al-anam features different types of rhyme: the rhyme at the end of the prose speech units in $s^{\prime}{ }^{c}$ and the rhyme combined with the poetic metres. The rhyme letter may change within a paragraph and, occasionally, even within a passage in verse, but is always an end rhyme. This formal feature is different from Dravidian poetry, where poets and bards prefer to have the beginning of lines rhyming with each other (first-phoneme and second-syllable rhymes, see Gamliel 2020, 268-69).

This short passage from the introduction contains various stylistic devices, such as rhyme (-lā), parallelism (wa-kammala, wa-sharrafa), and assonance (marked in bold): ${ }^{27}$

al-Hamdu li-llāhi lladhì sharrafa l-anāma bi-șāhibi l-maqāmi l-a lā * wa-kammala ssu'ūda bi-akrami mawlūdin hawā sharafan wa-fad̆lā * wa-sharrafa bihi l-ābā’a wal-judūda wa-mala'a l-wujūda bi-jūdihi 'adlā * hamalathu ummuhu Āminatu fa-lam tajid li-ḥamlihi alaman wa-thiqlā *

Praise be to God who honoured humankind with the possessor of the highest sta-

26 Those authors who participated in the transmission and compilation of events related to the prophet's biography.

27 al-Barzanji et al. (2008, 56-57). Translations are mine if not indicated otherwise. 
tion * Who completed the good fortune through the most noble new-born encompassing honour and merit * Who honoured the fathers and forefathers through him and filled existence by his generosity * When his mother Âmina was pregnant with him, she felt neither pain nor burden *

The quote below is taken from an episode included in one or the other form in many mawlid texts. It narrates how, during Āmina's pregnancy, every month a prophet visits her in her dream and tells her about the special qualities of her child. In our example, every sentence introduces a different prophet and therefore a different quality of the child and furthermore a different rhyme (al-Barzanji 2008, 63-64). Note that, as a rule in saj', the end-consonant is read in pausal form, i.e., without any following vowel (marked in bold).

Awwala shahrin min shuhūri hamlihā atāhā fì l-manāmi Ādam * wa-a lamahā annahā ḥamalat bi-ajalli l-'ālam * ash-shahra th-thāniya atāhā fì l-manāmi Idrīs * waakhbarahā bi-fakhri Muhammadin wa-qadrihi n-nafīs * ash-shahra th-thālitha atāhā fi l-manāmi Nūḥ * wa-qāla lahā: innaki qad hamalti bi-ṣăhibi n-nașri wa-l-futūḥ * ashshaḥra r-rābi'a atāhā fì l-manāmi Ibrāhìm al-khalìl * wa-dhakara lahā fạ̣la Muhammadin wa-mahallahu l-jalìl *

In the first month of her pregnancy, Adam came to her in her dream * and informed her that she was pregnant with the most exalted of the world * In the second month, Idris came to her in her dream * and told her about the glory of Muhammad and his precious rank * In the third month, Noah came to her in her dream * and said to her: you are pregnant with the possessor of victory and triumph * In the fourth month, Abraham the friend [of God] came to her in her dream * and told her about the merit of Muhammad and his sublime rank *

The passage is structured through a strong syntactic parallelism at the beginning of each sentence, starting with the second month. Every name of a prophet-or his epithet-rhymes with a quality of Muhammad. The combination of rhyme and parallelism was typical of early Arabic orations and became a figure praised by later critics, as Tahera Qutbuddin $(2018,119)$ shows in her study of a sermon by 'Alì ibn Abī Țālib (d. 661): "Rhyme and parallelism were not mutually exclusive; the phrases which culminated in the rhyme were frequently parallel as well. Indeed, authors of medieval chancery manuals praised the combination and had a special name for it: tașī ${ }^{\complement}$. Consonant-rhyme teamed with parallelism is featured in several lines of 'Alī's sermon." In our example, the rhyme changes each sentence, but there are longer passages that contain parallelism and the same rhyme in other parts of the text.

We also find a rather elaborated figure of speech, a form of paronomasia (root play): the fourth line features a graphic paronomasia (jinās musaḥhaf) with the words khalil / jalil. This figure is only noticeable in the Arabic script: the lexemes look almost identical, only the position of the dots is different (خليل | جليل). Besides this last figure of speech, it should be emphasised that most of the devices are based on auditory features, such as the rhythm created by parallelism, or the sound of rhyme and assonance. These elements create an efficacious auditory experience and mark the composition as a text that is primarily made for reciting and listening. 


\section{Mawlid as a Practice}

From the fourteenth century onwards, we find indications that mawlid texts were publicly recited (Katz 2007, 56, 72, 82, 2019). "Publicly" means they were read in front of an audience; the venue could be a private home, a mosque, or a zāwiya (place of a Sufi congregation). The occasion for such a recitation was the commemoration of the prophet's birth in the respective season, i.e., roughly the first half of the month $\operatorname{Rabi}^{\mathrm{c}}$ al-awwal, the third month of the Islamic lunar calendar. ${ }^{28}$ By the late fifteenth century, mawlid recitations had become common practice during other times of the year as well, detached from the birth. The communal mawlid reading - comprising not only the recollection of the prophet's birth but also praise of the prophet and the invocation of blessings for the prophet-had gained the status of a religiously meritorious act. Readings were held on occasions that would call for gratitude or ask for God's blessings, such as an engagement, a wedding, or a boy's circumcision (Katz 2007, 72-73, 2019).

Today, large parts of the mawlid are recited in a responsorial manner between a solo reciter and a group. At least the invocation of blessings for the prophet (tasliya) is performed by all participants of the occasion. ${ }^{29}$ The question of historic practices demands further research. A detailed reconstruction of historic recitation practices is difficult and, in many respects, impossible. Nonetheless, there are indications that the communal-and audible-performance of invocations of blessings for the prophet was part of a mawlid reading also in historic times. The Syrian poetess ' $\overline{\mathrm{A}}$ 'isha al-Bā' ūnīya (d. 1516) witnessed a mawlid reading during her pilgrimage stay in Mecca around 1475 and she reports: "It was Friday night, and I reclined on a couch on an enclosed veranda overlooking the holy Ka'bah and the sacred precinct. It so happened that one of the men there was reading a mawlid of God's Messenger, and voices arose with blessings upon the Prophet" ('Ā'isha al-Bā' ūnìya, quoted in Homerin 2013, 130-31).

Occasionally, we find the invitation to invoke blessings for the prophet included in manuscripts, and for many prints, it has become standard to include it. Such an invitation to invoke blessings can take various forms, ranging from a short formula (commonly șallü 'alayhi wa-sallimū taslimāa) to embellished rhymed verses. ${ }^{30}$ Hence, the performance of a mawlid text is not limited to a solo reciter but involves the audience, who become active participants in the event by uttering the invocation. Equally, the tasliya is more than an automated response to the mention of the prophet. Muslim scholars considered the inclusion of the tasliya as the most appropriate way to articulate a supplication and furthermore as a tool to increase its potential answer (Meier 1992). As mentioned above, a mawlid reading was not only a way to commemorate the prophet's birthday but was carried out to express gratitude or joy, or to ask for support. Against this backdrop, the communal performance of the tasliya within a mawlid reading is marked by polyvalence; it works as a participatory element to include the

28 The prophet's birthday is nowadays commonly dated to $12^{\text {th }} \mathrm{Rabi}^{\mathrm{i}}$ al-awwal; Twelver Shiites tend to set the date to $17^{\text {th }}$ Rabi $^{\mathrm{c}}$ al-awwal. However, recitations and festivities often started from the beginning of the month (for instance, Shinar 1977, 381-82). Today, celebrations are organised throughout the season up to three weeks after $12^{\text {th }}$ Rabī $^{\text {c }}$ al-awwal.

29 Recitation practices vary locally but the communal invocation of blessings is a stable element; see Al Faruqi (1995, 17-19); Muneer (2015, 11-12); observations during mawlid celebrations in Syria and Lebanon in the years 2009 to 2013 by the author.

30 For instance, Mawlid al-'Arūs, King Saud Library, 6274, F1/1262; Mawlid al-Barzanjī, State Library in Munich, Cod. arab. 2501. For various forms of invocations included in prints, see Abū l-Fath (1995); al-Barzanjī et al. (2008); al-Mālikī (1983); (Majmū'at ịhdā 'ashara rasā’il, n.d.); (Majmū'at Sharaf al-anām, n.d.). 
listeners, it is conceived as a means to ensure the efficacy of a supplication, and it constitutes a reward-wining act in itself (Katz 2007, 81-83; Weinrich 2016, 123-24).

Further ritual elements related to mawlid texts include the practice to stand up when the reciter reaches the event of Muhammad's birth (qiyām). This practice is generally traced back to an event in Damascus and two lines of a praise poem by the thirteenth-century author Yahyā ibn Yūsuf aṣ-Ṣarșarī (1989, 53):

It is not enough to praise the Chosen One [i.e. Muhammad] by writing in golden letters / on silver in best script

Nor is it enough that the noble men when they hear it / stand up in lines or fall on their knees

The prominent Mamluk scholar Taqīddīn as-Subkī (d. 1355) once attended a full recitation of the Quran in the Umayyad Mosque in Damascus. When he heard these verses recited during the event, he got up and stood, and the men around him did the same. This incidence, reported by his son Tājaddīn as-Subkī (d. 1370), generally is named as the first standing in honour of the prophet (Katz 2007, 128-29; Kayyāl 1984, 120). In the mid-sixteenth century, we find writings that confidently defend the practice of qiyām during mawlid recitations against critics. This suggests that it was an established practice by that time (Katz 2007, 129).

Closely connected to the practice of qiyām are verses in the form of 'welcome-songs': passages of poetry which directly address the prophet, like "Welcome, oh Light of My Eyes" (Marhaban yā nūr 'aynī) or "O Prophet, peace be upon you" (Yā nabī [alternately: Yā rasūl] salāmun 'alayka). There is reason to assume that these verses were in many cases later additions, since especially popular verses migrated between different mawlid texts and are also included independently in compilations of devotional texts (63 Waka mawlid kitab, n.d., 14546; al-Barzanjī 2008, 134; Katz 2008, 273; Muneer 2015, 13; Salakidis 2018, 347). Today, such verses are commonly chanted by all participants. Mawlid recitations seem to have ended regularly with a supplicatory prayer $\left(d u^{c} \bar{a}^{\prime}\right)$. Commonly, the prayer addresses general petitions for wellbeing, health, the prophet's intercession, and God's forgiveness. Many texts, both in manuscript and in print, include such a prayer. Depending on the ritual practices of the respective communities, this prayer may be accompanied by bodily acts, such as standing or raising the arms or hands.

Further practices related to mawlid readings varied according to time and space and will be mentioned only briefly. Accompanying activities include decorating the place and the burning of scented wood or incense during the reading. People not only express their plea for God's blessing and his forgiveness through organising and financing a mawlid reading, but they can take part in the economy of gifts and rewards by being responsible for single elements of a mawlid performance, such as providing food, scented water, or sweets that are distributed during a reading (Katz 2007, 63-103; Kayyāl 1984, 121, 123; Muneer 2015, 15).

\section{The Arabic mawlid in Transcultural Perspective}

The immensely wide distribution of compilations, both in print and as manuscript, of the majmü' $a$-type containing Sharaf al-anām as well as stand-alone copies of Sharaf al-anām suggests the text was well known in the Arab lands and beyond. Interestingly, Katz $(2008,474)$ notes that Sharaf al-anām is very popular in contemporary Yemen and that its popularity there is 
historically rooted. The remark by the aforementioned scholar Ibn ad-Dayba' (d. 1537) that he finally identified the author of Sharaf al-anām indicates that the text was known during his lifetime in Yemen. 'Abdalqādir ibn Shaykh al-'Aydarūs, who informs us about this, further adds the remark that he heard "many people" ascribing the text to the Hanbali scholar "Abdarrahmān Ibn al-Jawzī (d. 1200) instead. This remark supports the assumption that the text Sharaf al-anām was widespread, since "many people" talk about it (al-Aydarūs 2001, 292). A link between Yemen and India is not only provided by the 'Aydarūs family but, though indirectly, by Ibn ad-Dayba'. Ibn ad-Dayba', with the full name 'Abdarrahmān Ibn ad-Dayba' az-Zabīdī, was a Shāfíi scholar and historian who spent most of his life in his hometown Zabìd in the Tihama during the reign of the Țāhirid dynasty in Yemen. Ibn ad-Dayba's father migrated to India ("bilād al-Hind"). He never met his father, but news and money travelled between both regions, since he inherited a small sum of money from his father which he spent for his first pilgrimage in 1479. In 1491, following his third pilgrimage, he studied in the Hijaz with the renowned Egyptian scholar Shamsaddīn Abū 1-Khayr Muhammad as-Sakhāwī (d. 1497). Among Ibn ad-Dayba's historic works that survives is a history of his native town under the title Bughyat al-mustafid fi akhbār madinat Zabid. ${ }^{31}$ It describes a mawlid celebration under the Ṭāhirid ruler al-Malik al-Manșūr in 1485 and mentions that a mawlid reading (qirā'at mawlid an-nabi) was ordered (Ibn ad-Dayba' ${ }^{\prime} 1983,165$ ). This shows that mawlid reading was practiced in Zabīd already before he met as-Sakhāwī, one of the most prominent proponents of mawlid. It nevertheless does not exclude the possibility of as-Sakhāwī having an impact on a positive attitude towards mawlid writing among Arab as well as South Asian scholars in his teaching circles. as-Sakhāwī wrote a mawlid text that unfortunately only survives in short quotations (Katz 2007, 78). Ibn ad-Dayba's own mawlid text is still popular today (Katz 2008; Knappert 1988, 214, interview with Shaykh Muștafā al-Ja'farī, 24.06.2013 in Beirut).

The investigation of mawlid thus includes the traveling of practices, knowledge, and schol-

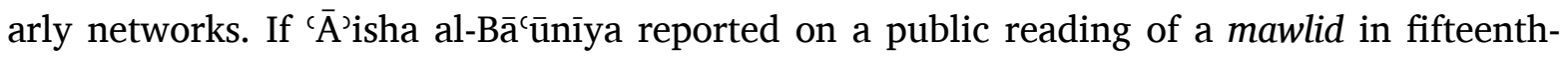
century Mecca, others must have heard such readings, too. The Hijaz constituted an important hub, as it was common that scholars and pilgrims spent long sojourns there either to teach or to study. Especially Mecca was a significant contact zone for Muslim scholars from West and East Asia. Ibn ad-Dayba' stayed there for a considerable period during his pilgrimage, as did ' $\bar{A}$ 'isha al-Bā' ūnīya. The Shāfi'ī scholar as-Sakhāwī repeatedly left his native city Cairo for pilgrimage and to spend time in the Hijaz for teaching and interacting with scholars from the Muslim East (Petry 1995).

In the case of Zaynaddīn ibn 'Alī ibn Aḥmad al-Ma'barī al-Malībārī (d. 1522), the presumed author of the Manqūs Mawlid, not only Mecca was a place of education. He travelled further to Cairo to study at the al-Azhar (Amer 2019; Kooriadathodi 2016, 211). Information on Zaynaddīn ibn 'Alī ibn Aḥmad al-Ma'barī al-Malībārī and his family is sparse and often conflicting. For the following short notes on his biography, I mainly use Amer (2019) and Kooriadathodi (2016, 209-12). Zaynaddīn ibn 'Alī ibn Aḥmad al-Ma'barī al-Malībārī (hereafter Zaynaddīn I) hails from a family of scholars that claims a Yemeni origin. In the fifteenth century, the family moved from the Coromandel Coast (Arab. al-Ma'bar, lit. the place where one crosses,

31 He later added a supplement. The edition I used bears the title of the supplement but contains both works. Briefly on Ibn ad-Dayba's biography, see Arendonk and Rentz (1971); I furthermore used his autobiographical account which is reproduced with additional material by al-`Aydarūs (Ibn ad-Dayba' 1983, 217-21; al-Aydarūs 2001, 286-95). 
namely Arab boats en route to China) to the Malabar Coast. ${ }^{32}$ The family first settled in Kochi, then in Ponnani. Zaynaddin I received his first education in Malabar and then spent at least six years in Mecca from where he travelled to Cairo. Among his most prominent teachers in Cairo were Zakariyyā' al-Anșārī, the Shāfi'î mufti and later chief judge (qāọì l-quḍāt), and asSuyūṭī, the author of the abovementioned fatwā Husn al-maqșid fi 'amal al-mawlid (The Good Purpose in the Observance of the mawlid). Upon his return to Ponnani, Zaynaddin I worked as a teacher and jurist. He wrote several books on mysticism (tasawwuf) and exhortation ( $w a^{\top} z$ ), but also on grammar, jurisprudence, and theology. ${ }^{33}$ His most renowned work seems to be Hidāyat al-adhkiy $\bar{a}^{\prime}$ ila tariq al-awliy $\bar{a}^{\text {) }}$ (Guidance for the Bright to the Path of the Friends of God), a versified manual on Sufism, which was commented several times and widely studied far beyond Malabar. ${ }^{34}$

By the time of Zaynaddin I-and partly owing to his activities-Ponnani had become an intellectual centre of the Malabar Coast. Through migration from the Coromandel Coast as well as from other parts of the Malabar Coast, the Muslim population in Ponnani had significantly grown in the second half of the fifteenth century. Immigration was intensified through Portuguese hostilities, when in the early sixteenth century Muslim merchant families left for Ponnani, especially from Portuguese-dominated Kochi (Kooriadathodi 2016, 210). With its newly established mosques and educational institutions, the city attracted many students and became the scene of a vibrant scholarly and ritual life, known as "Little Mecca" or "Mecca of South India" (Kooriadathodi 2016, 209). Students still travelled to Arab lands to pursue further education, but no longer to Cairo but to Mecca (Kooriadathodi 2016, 212). Zaynaddin II (d. 1579), ${ }^{35}$ grandson and namesake of Zaynaddīn I, spent around ten years in Mecca, where he studied, inter alia, with Ibn Hajar al-Haytamī (d. 1567), an eminent Shāfíī scholar from Cairo who had resided permanently in Mecca since 1533 and was the author of several works on the mawlid (Kooriadathodi 2016, 196). ${ }^{36}$ Besides this, Ponnani became a place of learning for Muslims from Hadramawt, Sri Lanka, or Indonesia (Kooriadathodi 2016, 212).

Hence, by the sixteenth century, we can ascertain movements of knowledge networks in

32 In the Arabic tradition of biographic writing, the full names already provide insight into the biography of a person, such as places of living, religious affiliations, or professions. "al-Ma‘barī al-Malībārī" describes a person who moved from the Coromandel Coast to the Malabar Coast. Amer (2019) favours a different explanation for Ma'barī, namely its derivation from the Yemenite town Ma`bar.

33 Amer (2019); GAL II, 221; GAL S II, 311-12; the most extensive list of his writings is given in the Preface to Tuhfat al-mujāhidin, see Zaynaddīn II ([1405] 1985, 12-14).

34 GAL II, 221; GAL S II, 311-12; Kunhali (2004, 17-18, 89-90, passim); Zaynaddīn II ([1405] 1985, 13-14). Amer (2019) considers a poem inciting to jihad (Tahrị̣ ahl al-imān 'alā jihād 'abadat aṣ-șulbān) as his most famous work.

35 az-Zirikli (2002, 3:64). His death date is controversial, and the often-quoted work ascribed to him, Tuhfat al-mujāhidin, is equally disputed. In line with most of the secondary literature, M. Kooriadathodi (2016, 197n10) states it was written in the 1580s, though he points to the weak evidence $(2016,196)$. The reason why many authors set the date of the Tuhfat, and consequently the death date of Zaynaddin II, in the 1580s is that the Tuhfat includes incidents up to 1583. However, Tuhfat also contains a dedication to the sultan of Bijapur, 'Alī 'Ādil Shāh, whose rule ended in 1579-80. Meia Walravens has convincingly argued that the book might have existed in different versions for different audiences and that the dedication, which is only included in two of the four known manuscripts, was not necessarily an integral element of the book. Already M.J. Rowlandson, who sent his translation of one of the manuscripts in 1831 to the Oriental Translation Committee, remarked that the information on the years 1580-83 must have been added by a different author (Walravens 2019, 227, 230).

36 On Ibn Ḥajar al-Haytamī and his works, GAL II, 388; S II, 527-28; Abū 1-Fatḥ (1995, 143-84); Ibn Ḥajar alHaytamī (2001). These works deserve further investigation, since Ibn Hajar al-Haytamī has been confused occasionally with Ibn Hajar al-'Asqalānī (d. 1449) as author. 
multiple directions, not only the typical arrows that have for a long time dominated in studies of cultural contacts, but also circles (Flüchter and Schöttli 2015). From the thirteenth century on, there is a strong movement from Yemen towards Malabar through emigration. Besides, pilgrims and students move from Malabar to the Hijaz and, eventually, Cairo and back again. By the sixteenth century, Mecca was the primary location of learning abroad for students from the Malabar Coast, and Ponnani emerged as a new place of education that attracted students from Hadramawt, South Asia, and Southeast Asia. It is not unlikely that Manqūs Mawlid was composed in such an environment and that mawlid texts such as Sharaf al-anām were known by Muslims in Malabar.

\section{Sharaf al-anām and Manqūṣ Mawlid: A Preliminary Comparison}

We have seen so far that Sharaf al-anām covered an impressive geographical span from Andalusia, where it is considered to have been composed in the thirteenth century, to Yemen, where it is mentioned by Ibn ad-Dayba', and finally to India, where the question of its authorship is addressed by a member of the 'Aydarūs family in late sixteenth-century Gujarat. It is furthermore included in modern devotional text compilations from South and Southeast Asia. Going beyond the travel of a single text, however, questions about literary networks must also address form and style and the wider context of mawlid compositions.

Manqūs Mawlid attributed to Zaynaddīn I is one of the most popular mawlid texts performed in Kerala today (Muneer 2015, 12). Muneer (2015, 13n38) cites its popular etymology, according to which manqūs refers to the idols in Mecca being upside down (Arab. n-k-s) when Muhammad was born. ${ }^{37} \mathrm{He}$, however, sees the literal meaning, "the abridged" (Arab. n-q-ș), as more probable. Indeed, tracing manqūs to mankūsa ("were upside down"), the form used in the Manqūs Mawlid (63 Waka mawlid kitab, n.d., 33), would mean several linguistic transformations. ${ }^{38}$ Yet, there is another reason for taking manqūs as referring to an abridged mawlid text. Manqūs Mawlid shares with other mawlid texts the composition technique of compiling a narrative around the prophet's birth from different source material into a short work that is apt for communal reading. This will become clear in a closer examination of the composition's structure. The following remarks are based on the text of Manqūs Mawlid as printed in 63 Waka mawlid (63 Waka mawlid kitab, n.d., 28-40), which is, at large, identical to the version in Mawlid kitāb (Mawlid kitab, n.d., 27-36). Since I had no access to any existing manuscripts against which to check these prints, I limit my analysis to the general formal features and content alignment. Any deeper linguistic and stylistic analysis must include available manuscripts of the text.

The Manqūs Mawlid bears similarities with and builds heavily on the model of Sharaf alanām. First, it shares the general formal structure, such as the introduction in saj', a sequence of narrated episodes and poems, the insertion of Quranic quotes, and a concluding prayer $\left(d u^{c} \bar{a}^{\prime}\right)$ in $s a j^{c}$. Second, the text is prosimetric and shifts frequently between $\operatorname{saj}^{c}$, prose, and

37 This motif is one of the many signs that occurred in the night of the birth and are enumerated in mawlid texts.

38 Commonly, the Arabisation of foreign terms was achieved by replacing consonants with those emphatic consonants the Arabic alphabet provided, for instance $/ \mathrm{t} / \mathrm{by} / \mathrm{t} / \mathrm{or} / \mathrm{d} / \mathrm{by} / \mathrm{d} /$. In the case of mankūsa/manqūs, to replace / k/ by /q/ and /s/ by /s / would mean the Arabisation of an already Arabic word, paired with the assimilation of the female form to the masculine form to have the participle congruent to the masculine lexeme mawlid. This etymology, deriving from an 'over-Arabisation' as a case of hypercorrection, is not completely improbable, though. 
poetry. Third, the author applies the technique of compiling the text from different source materials without necessarily creating a linear narrative. His introduction takes up motifs typical of mawlid introductions, such as Muhammad's beauty, his unique position among the other prophets, and the mentioning of some occurrences during pregnancy and birth. While these characteristics are shared by most mawlid texts, Manqūs Mawlid shares with Sharaf alanām the absence of explanatory passages and the prominent position of poems. Almost half of both texts consists of poetry. Moreover, the first episode on the beginnings of his prophethood and the primordial light is identical almost verbatim with a version of the same episode in Sharaf al-anām. For the assessment of this passage, some explanation is needed.

The brief episode bears reminiscences to the so-called Ka $\mathrm{b}$ narrative and the Jābir narrative, named after two companions of the prophet, Ka'b al-Aḥbār and Jābir ibn 'Abdallāh al-Anșārī, and analysed in length by Katz (2007, 12-29). Whereas the Kacb narrative focuses on the Muhammadan light which exists already before Adam and all other prophets, in the Jâbir narrative, the entire cosmos is created from that light: "Unlike the Kacb narrative, which describes the creation of the Prophet against the background of an already created earth and an audience of angels, the Jābir narrative regards the Light of Muhammad as the primordial substance of all creation" (Katz 2007, 24). In both narratives, however, the light, installed into Adam, is passed from prophet to prophet and to pure people, until Muhammad is born. The version in Sharaf al-anām and Manqūs Mawlid is introduced only by the passive voice "it is reported (ruwiya) from the prophet" without reference to a name of a transmitter.

Content and wording of the episode's second part is close to a Hadith traditionally traced to Ibn 'Abbās, a paternal cousin and companion of the prophet. This Hadith is, inter alia, included into a renowned work on Muhammad's qualities, al-Wafā bi-aḥwāl al-Muștafā (The States of the Chosen Prophet) by the aforementioned Hanbali scholar Ibn al-Jawzì. Being asked where he was when Adam was in paradise, Muhammad answers he was [a light] in his loins and was passed to other prophets and pure people. The respective passage in al-Wafa goes: "It is transmitted by Ibn 'Abbās: I asked: O Messenger of God, where were you when Adam was in paradise? He answered: I was in his loin, and I descended with him down to earth while I was in his loin, and I climbed the arch in the loin of Noah, and I was cast into fire in the loin of Abraham. [...]" (A. 1.-F. ‘. Ibn al-Jawzī, n.d., 1:70-71). The initiating question is not included in Sharaf al-anām and Manqūs Mawlid, where the complete episode appears as follows:

It is transmitted by the prophet (s): I was a light in the presence of God the Exalted two thousand years before he created Adam ( $($ ), and that light praised God, and the angels glorified it, and when the Sublime God created Adam ( () he installed that light in his clay (tinatihi). And God had me descend in the loin of Adam (c) down to earth, and he brought me on the arch in the loin of Noah, and he put me in the loin of Abraham al-Khalil ( $($ ) when he was cast into fire. And he continued to pass me from pure noble loins into pure noble wombs, until he brought me forth (akhrajanī) from my parents, and they have never committed fornication. (63 Waka mawlid kitab, n.d., 29; al-Barzanjī 2008, 60, the version in Barzanjī et al. differs only slightly in wording from 63 Waka mawlid, for instance in the use of eulogies and adjectives.)

Ka'b al-Ahbār is mentioned as a source in the next episode of the Manqūs Mawlid. This episode captures the heavenly rejoicing at Muhammad's conception and continues with the account of Āmina's pregnancy. Like in in the above-quoted passage from Sharaf al-anām, the 
individual nine months are enumerated and connected to qualities of the prophet. However, there are also differences: in the Manqūs Mawlid, not only prophets but also angels are involved who announce qualities of the unborn child and occurrences to be expected. On a formal level, both episodes are in $s^{\prime} j^{`}$. While there is no strict syntactic parallelism in Manqūs Mawlid like in Sharaf al-anām, the rhyme stays throughout the passage, which gives it a pronounced rhythm as well (63 Waka mawlid kitab, n.d., 30-31; al-Barzanjī 2008, 63-64). I will demonstrate these similarities with the last four months of the enumeration, a passage that is marked by syntactic parallelism, assonance, and rhyme (63 Waka mawlid kitab, n.d., 31):

Wa-atāhā fi Dhì l-Hijjati Mūsā l-kalīm (') wa-a lamahā bi-rutbati sayyidinā Muhammad (ș) wa-jāhihi l-asnā * wa-nādāhā fi Muharramin Jibrï (`) bi-'anna waqta wilādatihā qad dañ $\bar{a}^{*}$ wa-șțaffati l-malā’ikatu manzilahā fì Șafar fa-'alimat anna maw'ida s-surūri qad qaruba wa-danā * fa-lammā halla Rabīu l-awwali ạ̣̄àati l-arḍu wa-ssamā wa-ashraqati l-baytu wa-ṣ-șafä *

In Dhū l-Hijja, Moses came to her and informed her about the rank of our Lord Muhammad and his outstanding position * In Muharram, Gabriel announced that the time of birth had neared * In Șafar, the angels surrounded her house, and she knew that the time of joy had become near and close * And when Rabī alawwal began, earth and heaven became illuminated, and the house and [the hill of] aṣ-Ṣafā were radiating *

The Manqūs Mawlid furthermore contains the motif of the white bird whose wings touch Āmina when she gives birth (63 Waka mawlid kitab, n.d., 31). This motif is not included in Sharaf al-anām but in other mawlid texts, such as in the very popular Mawlid al-'Arūs, whose provenance is equally difficult to determine. Its title is derived from the introduction's opening line: "Praise be to God who from the blaze [on the forehead] of the bride ('arūs) of the Presence brought forth a radiant dawn" (Abū l-Fath 1995, 1:78). Mawlid al-'Arūs is generally ascribed to the Hanbali scholar Ibn al-Jawzī, author of the just mentioned al-Wafā bi-ahwāl al-Mustafä. ${ }^{39}$ This is the very same scholar who, as al-'Aydarūs reports, is considered the author of Sharaf al-anām by many people in the sixteenth century. Sharaf al-anām and Mawlid al-'Arūs share many confluences. Both texts seem to have been well-known and widely distributed, though without validated attribution to a single author, since, according to al"Aydarūs, "many people" (kathïran mina n-nās) in his time ascribed Sharaf al-anām to Ibn alJawzī, the presumed author of Mawlid al-'Arūs (al-Aydarūs 2001, 292). Both texts take their title from the introduction's opening line and demonstrate the fluidity of some mawlid texts, since it is difficult to trace a stable version in the available manuscripts, and passages from both texts are found in works by different authors. Furthermore, both share a wide circulation throughout the centuries that is manifested in various manuscripts and prints from different regions. On a formal level, they share the inclusion of material not found in the official sira, the absence of lengthy discussions that interrupt the narrative flow, and a high frequency of poetry.

In the Manqūs Mawlid, moreover, the narration of the birth event is followed by a qașida, which is strongly modelled after a qașida that features in a number of mawlid texts. Both are composed in the metre al-kāmil and rhyme in -dū (including the first hemistich). In the

39 On the authorship of Mawlid al-'`Arūs, see Katz (2007, 51-53); for its passage including the white bird, Abū 1-Fath (1995, 1:99); Ibn al-Jawzī (n.d., 18). 
Manqūs mawlid, the qaṣida opens with Wulida l-ḥabïbu s-sayyidu l-muta'abbidū (The Beloved was Born, the Lord Who is to be Served) (63 Waka mawlid kitab, n.d., 31-32); in other mawlid texts, the opening line is Wulida l-habïbu wa-khadduhū mutawarridū (The Beloved Was Born with Rosy Cheeks). Since this qașida circulates in more than one text, I hesitate to ascribe it to an individual author without a more thorough examination of the relevant manuscripts. Significantly, it features both in Sharaf al-anām and Mawlid al-'Arūs (al-Barzanjī 2008, 6566; Abū l-Fath 1995, 100-101). Moreover, five hemistichs out of twelve verses are identical in both poems, the one in Manqūs Mawlid and in Sharaf al-anām. There are two possible explanations for this. First, we have only one qașida that circulated and was included in Manqūs Mawlid as well as in Sharaf al-anām/Mawlid al-'Arūs, albeit in different versions. Or, second, the qașida in Manqūs Mawlid was deliberately composed as a mu'äraḍa on Wulida l-habibu wa-khadduhū mutawarridū, that is, a poetic contrafactum using the same metre and rhyme, and later both poems were mixed up.

Finally, the Manqūs Mawlid includes the episode of a non-Muslim family who observe their neighbours celebrating mawlid and subsequently convert to Islam. As we have seen, such a tale features prominently in Sharaf al-anām-where it is set in Cairo-and in a few other texts and constitutes a topos of its own (Katz 2007, 74, 109).

In addition to the considerable popularity of Sharaf al-anamm itself, this story has been circulated by a number of the many authors who compiled their own mawlids from pre-existing materials. It seems to have enjoyed a degree of acceptance independent of its attribution to any particular mawlid text or author. Ibn Makkīya credits it in Durar al-Bihār to a Muhammad ibn Ḥātim, rather than to (the equally unidentifiable) 'Abd al-Wāḥid ibn Ismācîl (ms. Cairo, Dar al-Kutub, Ta'rikh no. 3807, 14b). (Katz 2007, 234n46)

'Abdalwāhid ibn Ismācīl is the name given in Sharaf al-anām (al-Barzanjī 2008, 91). Not surprisingly, a third name occurs in the Manqūs Mawlid; here, the story is based on a certain 'Alì ibn Zayd (63 Waka mawlid kitab, n.d., 36). No place name is given in the Manqūs Mawlid. The main plot does not differ considerably from the tale in Sharaf al-anām. However, the tale is enlarged at the end and differs in the narrative perspectives employed. It is also interesting to note that the main protagonist in the Manqūs Mawlid is not a Jewish couple, as in Sharaf al-anām and other texts, but a family with a dhimmi status, that is, members of a religious community that is granted a status of protection against the payment of a special tax under Islamic rule. Commonly, the status applied to Jews and Christians, but it occasionally was expanded to members of other communities. This small change could refer to an environment with more religious communities to address.

In sum, we can discern confluences not only with regard to content and formal elements, such as the combination of $s a j^{\varsigma}$, prose, and poetry, but also in the overall technique to create a text by compiling a selection of episodes into a narration furnished with an elaborated introduction and poetry. These confluences strongly suggest that Manqūs Mawlid builds on the model of Arabic mawlid texts such as Sharaf al-anām and Mawlid al-'Arūs that had been circulating in Yemen and probably among Malabar Muslims as well. Moreover, the composer of Manqūs Mawlid has arranged the material into a form that is apt for liturgical reading ( $q$ ir $\bar{a}^{\prime} a$ ) in one session: it is short enough; many passages are in ornate speech (saj) with pronounced rhythm and rhyme; it features a high frequency of poetry; and it concludes with a prayer $\left(d u^{(} \bar{a}^{\prime}\right)$. I am not arguing here that the author was trying to copy or imitate any of 
the existing mawlid texts. First, especially popular mawlid texts were highly fluid texts, and second, episodes on the light, the nine visitors in nine months, or the conversion are included in texts beyond Sharaf al-anām or al-'Arūs. Rather, the author is aiming at the form of texts like Sharaf al-anām or al-'Arūs. Not all content from Sharaf al-anām found its way into Manqus Mawlid. For instance, the depiction of the birth is rather short, and the passages on the wetnurse are completely missing. These differences point to the fact that the author, in taking existing mawlid texts as a model, gave primacy to appropriate mawlid as a genre and not a single text.

\section{Perspectives on Re-contextualisation: Form, Function, and Language}

I have shown that in structure and style, Manqūs Mawlid closely follows the form of early Arabic mawlid texts such as Sharaf al-anām or Mawlid al-'Arūs. Further research will have to include other mawlid texts from Malabar and to look at potential changes in form, content, and functions, such as the transformations of imagery and poetic forms, the inclusion of material which is not found in examples from the Arab world, and other strategies of domestication, that is, strategies which inscribe texts "with linguistic and cultural values that are intelligible to specific domestic constituencies" (Venuti 1998, 67). At this point, I will only add two preliminary short remarks. Compared with mawlid texts from the Arab world, it is remarkable that in Kerala we find a variety of mawlid texts not only on Muhammad but also on other Muslim figures that are relevant to the history of Islam in Malabar. These include Cheraman Perumal, a Hindu ruler and main protagonist of a number of origin narratives, ${ }^{40}$ and 'Abdalqādir al-Jīlānī, the eponym of the Qādirīya order, who is not only honoured with the Muhyìddīn Māla but also with a mawlid text (Mawlūd Tājaddīn al-Hindī al-Malïbārī [1312] 1894; 63 Waka mawlid kitab, n.d., 40-47). There are also indications that mawlid as a term was used for texts that did not necessarily follow the structure of the early Arabic mawlid texts in Malabar. It seems that a larger variety in form and content of mawlid compositions from Malabar occurred only after the initial phase that is traditionally set with Manqūs Mawlid. We must leave these questions for future research and will continue with the context of the Manqūs Mawlid.

Arafath sees in the highlighting of Adam an individual accomplishment by Zaynaddinn I and the author's strategy to strengthen Muslim identity and gather his Muslim fellows under this banner:

One important thing we can notice in Manqus is the narrative around the genealogy of Prophet Muhammed. In the height of Portuguese penetration in Malabar, Makdhum I (sic) [i.e., Zaynaddīn I] knitted together a long family history of Prophet Muhammed by genealogically connecting him to Adam, who, according to the Quran, was the first human and the first prophet. (Arafath 2018, 25)

In my view, the passage is rather owed to genre convention than an individual invention by a single author, since including the lineage of prophets back to Adam is common to most

40 One of the most widespread origin narratives on the first Muslim community in Kerala is the so-called Story of the Emperor Perumal (Arab. Qișat Shakarwati Farmāḍ); for a brief overview on different origin narratives, see Pearson (2011, 346-48); on Qisșat, see the recent study by Kugle and Margariti (2017). 
mawlid texts. In addition, the topos of Adam and the wandering light figures in numerous instances of praise poetry for the prophet (al-madih an-nabawī) and in works on the prophet's qualities from the twelfth century onwards (e.g., al-Būșinī 1955, 2 (verses 9-14 of the Hamzìya), 194 (verse 59 of the Burda); A. 1.-F. ‘. Ibn al-Jawzī, n.d., 1:70-71; al-Qāḍi Abū 1-Faḍl 'Iyāọ al-Yaḥṣubì, n.d., 1:166-67). It is likely that such works circulated among Malabar scholars as well. Zaynaddin I was almost certainly acquainted with the Burda, since one of his teachers in Calicut, Fakhraddīn Abū Bakr ibn Qāḍī Ramaḍān ash-Shāliyātī (d. 1493), composed a poetic emulation of this ode in the technique of a takhmis, that is, an amplification that adds three hemistichs to each line of the base poem, here the Burda (Muneer 2014, 270). Zaynaddin I was furthermore well-acquainted with al-Qāḍi 'Iyāḍ's work on the special qualities of Muhammad, ash-Shifā bi-ta'rīf huqūq al-Musțafā, which contains a version of the light narrative, since he composed an abridgment (mukhtașar) of ash-Shifā (Kunhali 2004, 87n32; Zaynaddīn II (Ạ̣mad Zayn ad-Dīn al-Ma'barī al-Malībārī) [1405] 1985, 12-13).

Nevertheless, this does not mean that the passage, together with the act of communal mawlid reading, did not function in the way Arafath describes. The advent of European naval power in 1498 brought dramatic changes for the different communities living in Malabar. Arafath sees the mawlid reading as a means to face the threats in early sixteenth-century South India, caused by war, diseases, and a new power.

Arab Muslims as well as local communities in the region were worried about a new religion, maritime distress, sea wars and new diseases such as syphilis, all of which came along with the Portuguese. Manqus endowed the Prophet as the 'saviour man' in duress and created new locations for liturgical ritual practices. (Arafath 2018, 25)

In a similar vein, Aram Kuzhiyan Muneer $(2015,13)$ states: "As the tradition goes, Shaikh Zainuddin composed this mawlud when approached by people from Ponnani and its neighbourhoods who were fearful of deadly disease breaking out in their midst." But why would Zaynaddin I compose a mawlid, a text celebrating the prophet's birth, on such an occasion? We find a possible explanation for this when we look at the overall development of mawlid practices two hundred years after the first mawlid texts emerged. As Katz $(2007,2019)$ has shown, by the late fifteenth century a mawlid reading was no longer limited to the commemoration of the prophet's birth in the month $\operatorname{Rabi}^{-}$al-awwal but had been extended to other occasions that would call for God's blessings and support. Mawlid readings were regarded as meritorious acts and expressed joy and gratefulness. Moreover, by the very nature of their content and text practices, mawlid readings included the performance of praise and the invocation of blessings for the prophet, two acts generally believed as earning the prophet's support in return. This support is conceptualised as the prophet's intercession (shafác $a$ ) with God for a supplication. ${ }^{41}$ By the time when Manqūs Mawlid was composed, then, the primary function of its reading may well have been one of rogation and supplication. From this perspective, the mawlid reading did not simply serve to strengthen the faith and identity of the Muslim community by recollecting the prophet's birth and his message; rather, by praising his perfect virtues and invoking God's blessings upon him, a mawlid reading offered the communal and active retrieval of Muhammad's support and succour through performance.

Two further potential indications for such a function should be mentioned here. These per-

41 The notion of a "panegyrical pact" of gift and counter-gift between poet/performer and prophet, that is, praise for intercession, had been established and mediated through the poetic genre of madih nabawi (Stetkevych 2010, esp. 91-92). 
tain to the concluding prayer and to the Quranic verse that is chosen for citation. With only contemporary prints available at hand, we have no way to tell from what period the concluding prayer $\left(d u^{(} \bar{a}^{\prime}\right)$ stems, and any definitive conclusion will need a thorough examination of the textual history of Manqūs Mawlid. Yet, it is tempting to note that the prayer contains some terms which hint to a context that Arafath and Muneer describe. It starts in a general and unspecific manner, addressing topics that are included in many prayers of this type, such as the plea for healing, forgiveness, and salvation. But then, in addition to the general supplications, the prayer tantalisingly mentions "ahl baladina" (people of our homeland) and "țā $\bar{u} n$ " (plague) next to "wabāa qātic" (drastic epidemic) (63 Waka mawlid kitab, n.d., 39).

Both țā $\bar{u}^{\mathrm{u}}$ and $w a b \bar{a}^{\prime}$ are terms for epidemic or mass disease. In the Arab lands of the Eastern Mediterranean, $t \bar{a} \bar{u}$ n became primarily associated with the plague or Black Death. The Black Death was a painfully familiar phenomenon for the region, and therefore a subject for Muslim scholars early on. The Cairo-based scholar and litterateur Ibn Abī Hajala (d. 1375) composed his treatise Daf' an-niqma bi-ș-ṣalāt 'alā nabi ar-rahma (Fighting the Adversities Through the Invocation of Blessings for the Prophet) on the occasion of the plague outbreak in 1362-64 and lists no less than 33 plague outbreaks from the pre-Islamic era to his lifetime. He gives a remarkably precise definition of both terms: Ibn Abì Hajala defines $t \bar{a}^{c} \bar{u} n$ as a specific mass disease and describes its plague-specific symptoms in detail. In contrast, he defines $w a b \bar{a}^{3}$ as an unspecific mass disease with the typical characteristics of an epidemic: the disease occurs in one region of the earth, is different from other diseases by its high degree of spreading and shows typical symptoms that may vary from one historic case to the next (Herdt 2017, 222). Thus, it is not unlikely that $t \bar{a}\left(\bar{u} n\right.$ and $w a b \bar{a}^{3}$ refer to a new epidemic disease in sixteenthcentury Malabar.

Furthermore, the supplication is articulated for the sake of ahl baladinā. This phrasing, referring to the inhabitants of a specific region, is rather uncommon in the concluding supplications of other mawlid texts. More common is the supplication for those who are present during the reading (al-ḥădirūn) and/or for all Muslims in general (al-muslimūn) instead of those living in a specific region.

Finally, the Manqūs Mawlid chose to quote but one verse from the Quran: "To you has come a messenger, from among yourselves, aggrieved by the hardship you suffer, concerned for you, kind and compassionate towards the believers (Q 9: 128)." The quote is inserted between the introduction and the first narrated episode (on the light) and thereby serves as a motto for the text. Keeping lacking evidence in the form of manuscripts in mind, one cannot help noticing that this quote resonates with the $d u^{(} \bar{a}^{\prime}$ and the adversaries the Muslim community was facing in early sixteenth-century Malabar. Such an extra-ordinary situation may explain why it was deemed necessary to compose a separate, local mawlid text instead of using the already existing ones.

Moreover, mawlid as a religious practice is not limited to the roles of a speaker and his audience but builds heavily on the interaction between performers and listeners and has a strong inclusive appeal. The communal performance of invocations and refrains works as a community-building tool and provides a new access to and experience of Arabic. The mawlid finds its audience-and participants-in the increasing number of immigrants and students in Ponnani and marks a new stage in the development of Muslim communities and the role of Arabic.

In parallel to the growing familiarity with the Arabic script through the educational institutions in Ponnani as described by Kooriadathodi (2016) and Arafath (2018, 2020), the 
mawlid genre can be regarded as a step in that process of reaching out for a broader Muslim Malabar audience, beyond the scholarly elite trained in Arabic. It might even have had an impact on establishing a vernacular Muslim language capable of addressing an even wider audience, culminating in a new poetic genre, namely the māla written in Arabic Malayalam, whose performance shows similar functions to the performance of mawlid (see Gamliel 2017 for occasions of māla performances). The first traceable example of Arabic Malayalam is the already mentioned Muhyìddin Māla, a lengthy poem praising the eponym of the Qādirìya order 'Abdalqādir al-Jîlānī composed by Qāḍi Muhammad in 1607. This composition is characterised by joining two literary traditions beautifully referred to in a meta-poetic statement by the composer as "pearl" and "ruby". In verse 142, al-Qāḍi Muhammad designates his poetic work as a garland he created by "weaving pearls and rubies together," or a work he has "strung by joining together pearl and ruby" (63 Waka mawlid kitab, n.d., 173; translations in Arafath 2020, 13; Gamliel 2017, 28). Gamliel takes this image as analogy to an earlier genre in Malayalam literature in "a language hybrid known as Maṇipravālam, 'rubies and corals'," an amalgamation of Malayalam and Sanskrit (Gamliel 2017, 25-26), and highlights the effect of contrasting colours in the new pair as opposed to the colour harmony of rubies and corals. Arafath interprets the pearl as referring to the Arabic script and the ruby referring to Malayalam language:

Qadi Muhammed seems to have deployed the allegory of 'pearl' (an expensive oceanic commodity) to designate the Arabic script that was the form of the Muhiyuddinmala, while using 'ruby' (an expensive terrestrial object) to denote polyglossic spoken Malayalam that formed the matter of the text. (Arafath 2020, 13-14)

I take 'pearl', furthermore, more concretely as referring to the Arabic poetic tradition. The imagery of the pearl evokes a metaphorical description of poetry which is deeply rooted in the Arabic literary culture. Arab philologists have likened poetry and prose to pearls that are either stringed or dispersed (nazm / nathr). Stringed pearls allegorically describe the wellordered words of poetry that are structured by rhyme and metre. As we have seen, Arabic poetry is marked by an end-rhyme. This feature indeed forms a contrast to the Dravidian tradition of first-phoneme rhymes, here represented by rubies. Yet the Muhyiddin Māla features both, first-phoneme and end-rhymes, thus stringing pearls and rubies together. And it might not be without significance that the poetic device of the end-rhyme must have been familiar to many Malabar Muslims through listening to mawlid recitations, through both $\operatorname{saj}^{`}$ passages and qașida.

\section{Multiple-Text Compilations: The Material Context of Performative Texts}

Let me end with a short example that shows the entanglement of technical terms, practices, and material objects rooted in manuscript cultures. Muneer mentions a special term applied to compilations that contain mawlid and other devotional texts, called sabeena or safeena.

Both Manqus and Sharraf al-Anam, like other mawluds and devotional songs, circulate in prayer manuals/pamphlets which are synecdochically called mawlud kitab (book of mawlud) or edu (literally "leaf" or "page" of a book)—more interestingly, 
these prayer manuals are also known as sabeenas/safeenas, a word which I learnt from my mother at a very early age and then kept hearing often as I grew up in a village in South Malabar. The word "sabeena" is a corruption of the Persian "shabeena" which means "nocturnal." Since Mappilas used to (and continue to) recite mawluds, malas, and other devotional songs, and a variety of litanies from the prayer book daily at night, most especially between maghrib (sunset prayer) and 'isha' (night prayer), the prayer book was also called sabeena/safeena metonymically, meaning "that which is recited at night." (Muneer 2015, 13-14)

Though Muneer favours the Persian etymology, there is plausibility for an Arabic etymology as well. I would like to offer, at this point, meanings and uses of safeena (Arab. safina) from the Arabo-Islamic book culture. In North Africa, Egypt, and the Eastern Levant, safina (lit. ship, vessel) is the name for collections of strophic poetry, mainly muwashshahăt. ${ }^{42}$ The term safina often features in the title where it is either combined with an author's name or woven into a typical ornate rhyming title. Dwight Reynolds $(2012,76)$ names safina as one of the terms for the 'songbook' genre that was "well-established and widespread from Morocco to Syria to Yemen from at least the $16^{\text {th }}$ century." He further gives an interesting observation about Yemen, where safina was used for collections of the Yemeni local strophic poetry (humaynī). More commonly, however, it was used as a scrapbook or notebook of different types of texts. It belonged to individuals who either copied single texts from books or wrote them down as they heard them performed (Reynolds 2012, 75-76, with further references for Yemen).

Moreover, there is a special binding technique connected to that term. In the Islamicate manuscript culture, safina designates a format in which the single pages are sewed together at the smaller side of the paper. It is held vertically when used, the sewing being at the top. This oblong format was used as a scrapbook, since it was typically light enough to be carried around, and it was also sold with empty pages on the book market (Scheper 2015, 260, 313). Reynolds $(2012,75)$ remarks he has never encountered a muwashshah collection in that format; however, the Berlin State Library hosts some manuscripts of strophic poetry in that format (average size $13 \times 21 \mathrm{~cm}){ }^{43}$ Taking safeena as an Arabic term, such a heritage from the Islamicate manuscript culture may alternatively explain why compilations that contain mawlid, prayers, and devotional poetry in Kerala are called this. The Arabic meaning of safina allows two interpretations of the term that connect to the manuscript culture: safina as a ship, evoked by the horizontal shape, or safina as a vessel that gets gradually filled by the scribe. It is probable that safina remained the term for collections-of performative texts written down over the course of time-even after their material shape was no longer connected to the specific binding technique; and the term continued to be used for printed volumes. Many mawlid compilations still possess a portable character since they are not heavy hardcover prints but have the size and weight of booklets.

Finally, Regula Burckhardt Qureshi mentions a use of the term safina among Pakistani Muslims which seems to be based on the definition of safina as a compilation of devotional poetry, maybe even in the form of a scrapbook collection. In her study on the Hindustani music tradition connected to the Sufi practice (qawwālì), she examines the status of written

42 A form of strophic poetry that emerged in Andalusia towards the end of the ninth century and swiftly spread towards the Arab West. Early muwashshahāt were designed for singing, thus the term defines both a poetic and a musical genre. 
sources. Despite the existence of written compilations of Persian poetry and of individual poets' works, she states, music performers as well as individual Sufis usually

[...] use such sources only as a reference or backup to their memory, and it is in this sense that they identify poetry and music as two contrasting domains of knowledge: 'ilm-e-safina (knowledge of the written page) and 'ilm-e-sina (the knowledge of the memory). (Qureshi 1991, 107)

The term safina, spreading across regions and languages, yet retains a semantic aspect that is shared in all described contexts: it denotes a collection of various texts, often compiled by an individual person from different sources; the criteria for selection are based on what one sees as worth obtaining, be it useful or beautiful; the texts are not necessarily religious but definitely belong to performative genres such as poetry, prayers, and mawlid.

\section{Conclusion}

Mawlid as a text for communal liturgical reading emerged in different cultural and historical settings and formed an important part of the literary networks between the Arab lands and the Malabar Coast. In my analysis of an early Arabic mawlid text from Malabar, Manqūs Mawlid, I have differentiated between traveling texts and traveling genres. Sharaf al-anām constitutes an example of a traveling text. In its function as a model for Manqūs Mawlid, however, the objective was not the imitation of a text but the appropriation of its form and thereby conceptualising a mawlid text as a genre. Furthermore, the investigation of practices that are related to mawlid texts is crucial for their contextualisation. In case of Manqūs Mawlid, it is demonstrative of the rise of Ponnani as a Muslim intellectual centre and points to an intensified role of the Arabic language (and script) in the Muslim community and ritual life beyond the core rituals of ritual prayer, or șalāt, and the canonical sermon, or khuṭa.

Texts like Sharaf al-anām moved across regions and were widely used in the Arab world and beyond, as manuscripts and compilations of devotional texts indicate. In the case of Manqūs Mawlid, one of the earliest Arabic mawlid texts from the Malabar Coast and ascribed to Zaynaddīn I (d. 1522), evidence from two different angles suggest that texts like Sharaf al-anām have served as a model for its composition. The first cluster of evidence comes from historical sources like historiographic writing and biographical dictionaries. These sources identify historical figures embedded in the scholarly networks between Cairo, the Hijaz, South Arabia, Gujarat, and the Malabar Coast. Ibn ad-Dayba' from Zabīd reports of mawlid readings in his hometown in the late fifteenth century. His father had migrated to India; and Ibn ad-Dayba travelled to the Hijaz where he spent a longer sojourn to study. Ibn ad-Dayba' furthermore claimed to have identified the author of Sharaf al-anām, which is a strong indicator that the text was known in Yemen. 'Abdalqādir al-'Aydarūs, writing from Gujarat, not only includes this incident in his entry on Ibn ad-Dayba's biography; he furthermore adds the remark that he heard many people ascribing the text to Ibn al-Jawzi instead. This shows that the text circulated in Gujarat as well. The presumed author of Manqūs Mawlid, Zaynaddīn I, would have become acquainted with the mawlid genre at the latest during his travel to the Hijaz and Cairo; yet it is not unlikely that it happened even before that in Malabar. Certainly, Arabic praise poetry for the prophet circulated among Malabar scholars, as the poetic emulations demonstrate.

The second cluster of evidence comes from the analysis of form and style. The author of 
Manqūs Mawlid applies the technique of compiling different source material on the prophet's birth and early life into a form that, by length and stylistic features, is suited for liturgical reading during a single gathering. Auditory features of rhythm and rhyme show in the long passages in saj ${ }^{`}$ and in qașida poetry. Overlapping in terms of content, as in episodes on the wandering light or in the qasiida, which follows the account of Muhammad's birth, point to Sharaf al-anām as a model as well but should not be overestimated, since these feature in a number of similar mawlid texts like Mawlid al-'Arūs. Rather, the fact that episodes from Sharaf al-anām are missing in Manqūs Mawlid shows that Sharaf al-anām was taken primarily as a genre model, whereas full congruence in terms of content was not the intention.

Manqūs Mawlid is traditionally linked to the wars and other adversaries following the Portuguese occupation of parts of Malabar and to the city of Ponnani, where Muslims from Kochi in the South and from Calicut in the North sought refuge. ${ }^{44}$ Textual evidence in the Quranic quote and the concluding prayer-provided that the prayer is not a later addition-support this timing. The composition of a performative mawlid text in times of crises blends well into the overall development of mawlid practices. By the late fifteenth century, a mawlid reading was no longer limited to the birth anniversary of the prophet but was performed on other occasions as well. A mawlid reading was deemed a meritorious deed and formed a supererogatory act of piety to which listeners could actively contribute, at least by performing the invocations of blessing. A mawlid reading was thus appropriate to secure the prophet's intercession for a supplication to God.

Manqūs Mawlid most probably did not address an audience that was completely unfamiliar with the mawlid genre. Mawlid may have been known in Malabar either through returnees from the Hijaz, through Muslim traders between Southeast Asia and the Eastern Mediterranean, or through immigrants from Yemen, where mawlid was firmly established by the lifetime of Zaynaddin I. Surely, to include the circulation of manuscripts is a desideratum because it would add further evidence. However, such an examination deserves a study of its own, not least due to the fact that a large part of manuscripts in Malabar is not publicly available but remains in private collections (Kooria 2018, xvi). In the case of mawlid, moreover, the evidence of manuscripts is not the only indication for the circulation of texts, because mawlid texts function as oral performances. A mawlid text was composed for primarily auditive consumption, and it is in this form that most Muslims would have encountered such a text. It is therefore not purely anecdotal when ' $\overline{\mathrm{A}}$ 'isha al-Bā' $\bar{u}$ inya reports that she listened to a mawlid in Mecca.

Mawlid readings, through their aesthetic features and the participation of listeners, offered a new experience of Arabic, both as a language of ritual and a language of poetry. This mirrors the social changes of the Malabar Muslim community, especially in Ponnani, which had become a centre of Muslim learning with a rising number of immigrants, educational institutions, and students. A growing educated group well versed in Arabic was the audience of literary productions like praise poetry for the prophet and mawlid. Hence, to analyse transregional literary networks, combining the evaluation of literary forms, linguistic transfer, and text practices constitutes a promising approach to the investigation of Indian Ocean historiography. From this angle, texts from the field of poetry and liturgy gain significance as sources for studying the development of the Muslim communities in Malabar.

44 The Zamorin of Calicut first allied with the Muslim population against the Portuguese, but later agreed to a treaty with the Portuguese with unfavorable conditions for the Muslims. On shifting alliances and wars, see Kooriadathodi (2016, 206-09); Prange (2018, 138-43); Walravens (2019, 231-32); Zaynaddīn ([1405] 1985, 245-302). 


\section{Acknowledgments}

This is the expanded version of a presentation given at the international workshop Arabic and Islam on the Move: Cross-cultural Encounters between Arabia and Malabar 900s-1500s, held at the Käte Hamburger Kolleg Dynamics of the History of Religions between Europe and Asia, RuhrUniversität Bochum, and organised by Ophira Gamliel (23-24 May 2017). I am indebted to the Käte Hamburger Kolleg and Ophira Gamliel for inviting me to the workshop. I thank Alex Cuffel for including my paper in this special issue on The Indian Ocean and its Periphery as well as both anonymous reviewers for their valuable observations and suggestions. Research for this paper is based on my project "Mawlid-texts from the 13th to the 18th century: Prophetic piety as ritual performance?," funded by the Deutsche Forschungsgemeinschaft (DFG)—reference number 389265477.

\section{Abbreviations}

GAL Brockelmann, Carl. 1902. Geschichte der Arabischen Litteratur, vol. 2, Weimar: Emil Felber.

GAL S Brockelmann, Carl. 1996. Geschichte der arabischen Litteratur. Zweiter Supplementband. Leiden: Brill.

\section{References}

63 Waka mawlid kitāb [A Book of 63 mawlid]. n.d. Thirurangady: C. H. Muhammad and Sons, 'Āmir al-Islām, Lithopowerpress.

Abū l-Fatḥ, Nawāl. 1995. al-Mutāh min al-mawālid wa-l-anāshīd al-milāh [The Ordained of mawlid and Praise Poetry]. Damascus: Dār ash-Shādī.

Alatas, Ismail Fajrie. 2014. "'Abdallāh b. 'Alawī al-Haddād." In Encyclopaedia of Islam Three, edited by Kate Fleet, Gudrun Krämer, Denis Matringe, John Nawas, and Everett Rowson. Vol. 1. Leiden: Brill.

Al Faruqi, Lois (Lamya'). 1995. "Mawlid and mālid: Genres of Islamic Religious Art from the Sultanate of Oman." In The Complete Documents of the International Symposium on the Traditional Music in Oman: October 6-16, 1985, edited by Issam el-Mallah, 3:17-34 Wilhelmshaven: Noetzel.

al-Qāọī Abū l-Faḍl 'Iyāọ al-Yaḥ̣ubī. n.d. al-Shifā bi-ta'rỉf huqūq al-Muṣtafā [The Healing through Knowing the Muhammadan Truth]. Beirut: Dar al-Kutub al-'Ilmìya.

Amer, Ayal. 2019. "al-Malībārī, Zayn al-Dīn." In Encyclopaedia of Islam Three, edited by Kate Fleet, Gudrun Krämer, Denis Matringe, John Nawas, and Everett Rowson. Vol. 6. Leiden: Brill.

Arafath, Yasser P. K. 2018. "Malabar Ulema in the Shafiite Cosmopolis: Fitna, Piety and Resistance in the Age of Fasad." The Medieval History Journal 21: 1-42. https://doi.org/10 $.1177 / 0971945817750506$.

- 2020. "Polyglossic Malabar: Arabi-Malayalam and the Muhiyuddinmala in the Age of Transition (1600s-1750s)." Journal of the Royal Asiatic Society 3: 1-23.

Arendonk, C. van, and G. Rentz. 1971. "Ibn al-Dayba'." In Encyclopaedia of Islam, edited by P. Bearman, Th. Bianquis, C. E. Bosworth, E. van Donzel, and W. P. Heinrichs, 2nd ed. Leiden: Brill. 
Aydarūs, 'Abdalqādir ibn Shaykh ibn 'Abdallāh al-. 2001. an-Nūr as-sāfir 'an akhbār al-qarn al-' $\bar{a}$ shir [The Unveiling Light on Reports of the Tenth Century]. Edited by Aḥmad Ḥâlū, Maḥmūd al-Arnā'ūṭ, and Akram al-Būshī. Beirut: Dār aṣ-Ṣādir.

Barzanjī, Ja'far ibn Hasan al-. 2008. Mawlid al-Barzanjī [The mawlid of al-Barzanjī]. Abu Dhabi: as-Sāḥa al-Khazrajīya.

Brown, James A. O. 2014. "Azafid Ceuta, Mawlid al-Nabi and the Development of Marinnid Strategies of Legitimation." In The Articulation of Power in Medieval Iberia and the Maghrib, edited by Amira K. Bennison, 127-51. Oxford: Oxford University Press.

Būṣīīi, Sharafaddīn Muhammad al-. 1955. Dīwān al-Būṣirī [The Diwan of al-Būṣīin̄]. Edited by Muḥammad Sayyid Kīlānī. Cairo: Maktabat wa-Mațba'at Muṣṭafā al-Bābī al-Ḥalabī.

Endress, Gerhard. 2016. “' 'One-Volume Libraries' and the Traditions of Learning in Medieval Arabic Islamic Culture." In One-Volume Libraries: Composite and Multiple-Text Manuscripts, edited by Michael Friedrich, Cosima Schwarke, and Cosima Schwarke, 171-205. Berlin: de Gruyter.

Fishtālī, Abū Fāris 'Abdal'azīz al-. n.d. Manāhil aṣ-ṣafā fì ma’āthir mawālīnā sh-shurafā [Bounteous Information on the Glorious Deeds of our Noble Lords]. Edited by 'Abdalkarīm Karīm. Rabat: Mațba'at Wizārat al-Awqāf li-sh-Shu'ūn al-Islāmīya wa-th-Thaqāfìya.

Flüchter, Antje, and Jivanta Schöttli. 2015. "Introduction." In The Dynamics of Transculturality: Concepts and Institutions in Motion, edited by Antje Flüchter and Jivanta Schöttli, 1-23. Heidelberg: Springer.

Gamliel, Ophira. 2017. "On the Warp and Woof of Language: Arabic, Malayalam and the Muhyidīn Māla." Ishal Paithrikam Thrimasika 15: 24-30.

- 2018. "Who was the Fadiyār? Conflating Textual Evidence in Judeo-Arabic and Old Malayalam." Ginzei Qedem Genizah Research Annual 14: 9-42.

- 2020. A Linguistic Survey of the Malayalam Language in Its Own Terms. Wiesbaden: Harrassowitz.

Gelder, Geert Jan van. 2012. Sound and Sense in Classical Arabic Poetry. Wiesbaden: Harrassowitz.

Graham, William A. 1983. "Islam in the Mirror of Ritual." In Islam's Understanding of Itself, edited by Richard G. Hovannisian and Speros Vryonis, 53-71. Malibu, California: Undena Publications.

Hees, Syrinx von, and Syrinx, eds. 2017. Inhịțāt - The Decline Paradigm: Its Influence and Persistence in the Writing of Arab Cultural History. Würzburg: Ergon.

Heinrichs, Wolfhart. 1997. "Prosimetrical Genres in Classical Arabic Literature." In Prosimetrum: Crosscultural Perspectives on Narrative in Prose and Verse, edited by Joseph Harris and Karl Reichl, 249-75. Woodbridge: Brewer.

Herdt, Andreas. 2017. "Ibn Abī Hağalah und sein Traktat 'Das Feien gegen jedwede Widerwärtigkeit mittels des Bittgebets für den Propheten der Gnade [Daf' an-niqmah bi-ṣ-șalāh 'alā nabì ar-rahmah]'." In The Sultan's Anthologist - Ibn Abì Hağalah and His Work, edited by Nefeli Papoutsakis and Syrinx von Hees, 209-47. Baden-Baden: Nomos.

Ho, Engseng. 2006. The Graves of Tarim: Genealogy and Mobility Across the Indian Ocean. Berkeley: University of California Press.

Homerin, Emil Th. 2013. “'Recalling You, my Lord: 'Ā'ishah al-Bā'ūnīyah on dhikr.” Mamlūk Studies Review 17: 130-54.

Ibn ad-Dayba', 'Abdarraḥmān ibn 'Alī. 1983. al-Faḍl al-mazìd 'alā bughyat al-mustafìd fĩ akhbār madinat Zabid [Utmost Favour for the Valuable Wish on Reports on the City Zabìd]. 
Edited by Yūsuf Shulḥud. Sanaa / Beirut: Markaz ad-Dirāsāt wa-l-Buhūth al-Yamanī / Dār al-'Awda.

Ibn al-Ḥājj, Abū 'Abdallāh ibn Muḥammad ibn Muhammad al-`Abdarī. n.d. al-Madkhal [Prolegomena]. Vol. 2. Cairo: Maktabat Dār at-Turāth.

Ibn al-Jawzī. n.d. Mawlid al-Jawzī aš-šahïr bi-l-'Arūs [The mawlid of Ibn al-Jawzī Known as al-'Arūs]. Beirut: al-Maktaba al-Unsīya.

Ibn al-Jawzī, Abū 1-Faraj 'Abdarrahmān. n.d. al-Wafā bi-aḥwāl al-Muștafā [The States of the Chosen Prophet]. Edited by Muḥammad Zuhayr an-Najjār. Riyad: al-Mu’assasa assa'īdiyya.

Ibn at-Tuwayr. 1992. Nuzhat al-muqlatayn fi akhbär ad-dawlatayn [A Stroll with the Eyes on Reports of the Two States]. Edited by Ayman Fu'ād Sayyid. Beirut: Franz Steiner.

Ibn Batțūța. 1879. Voyages d'Ibn Batoutah, Arabic Text and French Trans. Edited by C. Defremery and B. R. Sanguinetti. Vol. 4. Paris: L'imprimerie nationale.

Ibn Hishām. (1937) 1955. as-Sïra an-nabawìya li-Ibn Hishām [The Prophet's Biography by Ibn Hishām]. Edited by Mușțafā as-Saqqā, Ibrāhīm al-Abyārī, and 'Abdalḥafīz Shalabī. Cairo: Mușțafā al-Bābī al-Ḥalabī wa-awlāduh.

Ibn Ḥajar al-Haytamī. 2001. Itmām an-ni'ma al-kubrā 'alā l-'ālam bi-mawlid sayyid walad Ādam [The Completion of the Greatest Grace for the World through the Birth of the Lord of Humankind]. Edited by 'Abdal'azīz Sayyid Hāshim al-Ghazūlī. Beirut: Dār al-Kutub al-'Ilmīya.

Ibn Jubayr. 1959. Rihlat Ibn Jubayr [The Travelogue of Ibn Jubayr]. Beirut: Dār Șādir.

Ibn Khaldūn, 'Abdarraḥmān. 1911. Bughyat ar-ruwwād fï dhikr mulūk min Banī 'Abd al-Wād. Histoire des Beni 'Abd el-Wād, Rois de Tlemcen (Régne d'Abou H'ammou Moûsa II). Edited by Alfred Bel. Vol. 2. Algier: Imprimerie orientale, Fontana Frères \& Cie.

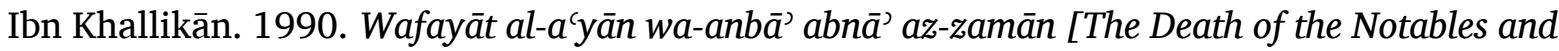
the News of the Sons of Our Times]. Edited by Iḥsān 'Abbās. Beirut: Dār ath-Thaqāfa.

Ibn Taymīya, Aḥmad. n.d. Iqtị̂ā' ass-ṣirāṭ al-mustaqìm li-mukhālafat aṣhāa al-jahīm [The Necessity of the Straight Path to Oppose the Followers of Hellfire]. Edited by Nāșir ibn 'Abd al-Karìm al-'Aql. Vol. 2. Riyad: Maktabat ar-Rushd.

Kaptein, N. J. G. 1993. Muhammad's Birthday Festival: Early History in the Central Muslim Lands and Development in the Muslim West Until the 10th/16th Century. Leiden: Brill.

Katz, Marion H. 2007. The Birth of the Prophet Muhammad: Devotional Piety in Sunni Islam. London / New York: Routledge.

— 2008. "Women's Mawlid Performances in Sanaa and the Construction of 'Popular Islam'." International Journal of Middle East Studies 40: 467-84.

. 2019. "Commemoration of the Prophet's Birthday as a Domestic Ritual in Fifteenthand Sixteenth-Century Damascus." In Domestic Devotions in the Early Modern World, edited by Marco Faini and Alessia Meneghin, 167-81. Leiden: Brill.

Kayyāl, Munīr. 1984. Yā Shām. Fì t-turāth ash-shabì ad-dimashqĩ [Oh Damascus: On the Heritage of Damascene Popular Culture]. Damascus: Mațba'at Ibn Khaldūn.

Kister, Meir J. 1979. “'Sha'bān is my Month...' A Study on Early Tradition.” In Studia Orientalia Memoriae D.H. Baneth dedicata, edited by Joshua Blau, 13-37. Jerusalem: The Magnes Press \& Institute of Asian and African Studies.

Knappert, Jan. 1988. “The Mawlid.” Orientalia Lovaniensia Periodica 19: 209-15. 
Kooria, Mahmood. 2018. "Introduction." In Malabar in the Indian Ocean. Cosmopolitanism in a Maritime Historical Region, edited by Mahmood Kooria and Michael N. Pearson, xv-xxvii. Oxford: Oxford University Press.

Kooriadathodi, M. 2016. "Cosmopolis of Law: Islamic Legal Ideas and Texts Across the Indian Ocean and Eastern Mediterranean Worlds." PhD diss, Leiden: Leiden University.

Kugle, Scott, and Roxani Eleni Margariti. 2017. "Narrating Community: The Qișat Shakarwati Farmā Economic and Social History of the Orient 60: 337-80.

Kunhali, V. 2004. Sufism in Kerala. Calicut: Calicut University Press.

Lambourn, Elisabeth. 2014. "Borrowed Words in an Ocean of Objects: Geniza Sources and New Cultural Histories of the Indian Ocean." In Irreverent History: Essays for M. G. S. Narayana, edited by G. S. Narayanan, Kesavan Veluthat, and Donald R. Davis Jr., 363414. Delhi: Primus Books.

Lev, Yaacov. 1991. State and Society in Fatimid Egypt. Leiden: Brill.

Majmū'at iḥdā 'ashara rasā'il [The Collection of Eleven Epistles]. n.d. Cairo: Mușțafā al-Bābī al-Halabī wa-Awlāduh bi-Mișr.

Majmū'at Sharaf al-anām [The Collection Sharaf al-anām]. n.d.

Mawlid kitāb [The Book of mawlid] [Compilation of mawlid Texts and Devotional Poetry]. n.d.

Mawlūd Tājaddīn al-Hindī al-Malībārì. (1312) 1894. Private collection of Sayyid Ali Halarmuth. Mattoul, Kerala.

Mālikī, Muhammad ibn 'Alawī al-Ḥusaynī al-, ed. 1983. Bāqa 'ațira min șiyagh al-mawlid wal-madā’hh an-nabawìya al-karima [A Fragrant Bouquet of mawlid and Praise Poetry].

Meier, Fritz. 1992. "Die segenssprechung über Mohammed im bittgebet und in der bitte." In Bausteine. Ausgewählte Aufsätze zur Islamwissenschaft von Fritz Meier, edited by Erika Glassen and Gudrun Schubert, 2:837-75. Istanbul: Harrassowitz.

Muneer, Aram Kuzhiyan. 2015. "Poetics of Piety: Genre, Self-Fashioning, and the Mappila Lifescape." Journal of the Royal Asiatic Society 3: 1-19.

Muneer, Aram Kuzhiyan Hudawi. 2014. "Praise Poetry, Keralite Tradition." In Muhammad in History, Thought, and Culture: An Encyclopedia of the Prophet of God, edited by Coeli Fitzpatrick and Adam Hani Walker, 2:469-72. Santa Barbara: ABC-Clio.

Neuwirth, Angelika. 2010. "From the Sacred Mosque to the Remote Temple: Sūrat al-Isrā' between Text and Commentary." In With Reverence for the Word: Medieval Scriptural Exegesis in Judaism, Christianity, and Islam, edited by Jane Dammen McAuliffe, Barry D. Walfish, and Joseph W. Goering, 376-407. Oxford: Oxford University Press.

Pearson, Michael. 2011. "Islamic Trade, Shipping, Port States and Merchant Communities in the Indian Ocean, Seventh to Sixteenth Centuries." In The New Cambridge History of Islam, Vol. 3: The Eastern Islamic World Eleventh to Eighteenth Century, edited by David O. Morgan and Anthony Reid, 3:317-65. Cambridge: Cambridge University Press.

Peskes, Esther. 2005. al-'Aidarūs und seine Erben. Eine Untersuchung zu Geschichte und Sufismus einer hadramitischen Sāda-Gruppe vom fünfzehnten bis zum achtzehnten Jahrhundert. Stuttgart: Franz Steiner.

Petry, C. F. 1995. "al-Sakhāwī." In Encyclopaedia of Islam, Second Edition, edited by P. Bearman, Th. Bianquis, C. E. Bosworth, E. van Donzel, and W. P. Heinrich. van Donzel: W.P. Heinrichs.

Prange, Sebastian. 2018. Monsoon Islam: Trade and Faith on the Medieval Malabar Coast. Cambridge: Cambridge University Press. 
Qureshi, Regula Burckhardt. 1991. "Sufi Music and the Historicity of Oral Tradition." In Ethnomusicology and Modern Music History, edited by Stephen Blum, Philip V. Bohlman, and D. M. Neumann, 103-20. Urbana / Chicago: University of Illinois Press.

Qutbuddin, Tahera. 2018. "A Sermon on Piety by Imam 'Alī ibn Abì Ṭālib: How the Rhythm of the Classical Arabic Oration Tacitly Persuaded." In Religion and Aesthetic Experience: Drama - Sermons - Literature, edited by Sabine Dorpmüller, Jan Scholz, Max Stille, and Ines Weinrich, 109-23. Heidelberg: Heidelberg University Publishing.

Reynolds, Dwight F. 1997. "Prosimetrum in Nineteenth- and Twentieth-Century Arabic Literature." In Prosimetrum: Crosscultural Perspectives on Narrative in Prose and Verse, edited by Joseph Harris and Karl Reichl, 277-94. Woodbridge: Brewer.

— 2012. "Lost Virgins Found: The Arabic Songbook Genre and an Early North African Exemplar." Quaderni Di Studi Arabi 7: 69-105.

Ricci, Ronit. 2016. Islam Translated. Literature, Conversion, and the Arabic Cosmopolis of South and Southeast Asia. Chicago / London: The University of Chicago Press.

Rubin, Uri. 2008. "Muhammad's Night Journey (isrā’) to al-Masjid al-Aqșā. Aspects of the Earliest Origins of the Islamic Sanctity of Jerusalem." al-Qanțara: Revista de Estudios Arabes 29: 147-64.

Salakidis, Georgios. 2018. "Islamische Frömmigkeit in griechischer Sprache: Ein griechisches Gedicht in arabischer Schrift auf die Geburt des Propheten Muhammad." In Linguistic Minorities in Turkey and Turkic-Speaking Minorities of the Periphery, edited by Christiane Bulut, 343-407. Wiesbaden: Harrassowitz.

Scheper, Karin. 2015. The Technique of Islamic Bookbinding: Methods, Materials and Regional Varieties. Leiden: Brill.

Schimmel, Annemarie. 1985. And Muhammad Is His Messenger: The Veneration of the Prophet in Islamic Piety. Chapel Hill: The University of North Carolina.

Shinar, P. 1977. "Traditional and Reformist Maulid Celebrations in the Maghrib." In Studies in Memory of Gaston Wiet, edited by Myriam Rosen-Ayalon, 371-413. Jerusalem: The Hebrew University in Jerusalem.

Stetkevych, Suzanne Pinckney. 2010. The Mantle Odes: Arabic Praise Poems to the Prophet Muhammad. Bloomington: Indiana University Press.

Suyūṭị, Jalāladdīn 'Abdarraḥmān as-. 1985. Husn al-maqșid fì 'amal al-mawlid [The Good Purpose in the Observance of the mawlid]. Edited by Mușțafā 'Abdalqādir 'Ațā. Beirut: Dār al-Kutub al-'Tlmìya.

Șarṣarī, Yahyā ibn Yūsuf aṣ-. 1989. Dīwān aṣ-Ṣarșarī [The Diwan of aṣ-Ṣarṣarī]. Edited by Mukhaymar Șāliḥ. Irbid: University of Yarmuk.

Ukeles, Raquel M. 2010. “The Sensitive Puritan? Revisiting Ibn Taymiyya's Approach to Law and Spirituality in Light of 20th-century Debates on the Prophet's Birthday (mawlid alnabi)." In Ibn Taymiyya and his Times, edited by Youssef Rapaport Youssef and Shahab Ahmad, 319-37. Karachi: Oxford University Press.

Venuti, Lawrence. 1998. The Scandals of Translation: Towards an Ethics of Difference. London and New York: Routledge.

Walravens, Meia. 2019. "Multiple Audiences of a History from Sixteenth-Century Malabar: Zayn al-Dīn al-Ma'barī's Gift of the Strugglers for Jihad." South Asian Studies 35: 226-36.

Weinrich, Ines. 2016. "Between Poem and Ritual: The Burda by al-Būṣīī (d. 1294-1297)." In Performing Religion: Actors, contexts, and texts. Case studies on Islam, edited by Ines Weinrich, 103-26. Beirut: Ergon. 
Winkler, Stefan. 1997. "Buchproduktion und Strukturen des Verlagswesens im heutigen Ägypten." Master Thesis, Bamberg: Otto-Friedrich-Universität Bamberg.

Zaynaddīn II (Aḥmad Zayn ad-Dīn al-Ma‘barī al-Malībārī). (1405) 1985. Tuhfat al-mujāhidīn [Gift of the Strugglers for Jihad]. Edited by Muhammad Sa'īd aț-Ṭurayḥi. Beirut: Mu’assasat al-Wafā'?

Ziriklī, Khayraddīn az-. 2002. al-A lām [Biographical Dictionary]. 8 vols. Beirut: Dār al-'Ilm li-l-Malāyīn. 